\title{
Factors affecting citizenship education according to perceptions and experiences of secondary-school teachers
}

\author{
Burcu Gürkan \\ Hasan Kalyoncu University, Faculty of Education, Gaziantep, Turkey, burcu.gurkan@hku.edu.tr \\ Ahmet Doğanay \\ Çukurova University, Faculty of Education, Adana, Turkey, adoganay@cu.edu.tr
}

Check for updates

ABSTRACT The present study examines the factors affecting citizenship education, such as school, environment, students, teachers, and the curriculum, as perceived and experienced by secondary school teachers. The study is qualitative and uses a phenomenological design. Maximum diversity sampling was used for selecting participants. The sample consisted by eight teachers of geography, history, and philosophy who worked in three different secondary schools in the Şahinbey district of Gaziantep province in the 2017-2018 academic year. The data was collected through semi-structured interview forms and analyzed through content analysis. The data revealed causality relations. The results of the study reveal that participants categorized the concept of citizenship and citizenship education as individual, state, rights, and responsibility, which is in line with the literature. All of the participants carried out studies on citizenship knowledge and skills during their teaching processes. It was discovered that citizenship education is realized through informal (unplanned) education together with curriculum content. According to participants, citizenship education is affected by various positive and negative factors such as students, teachers, and the curriculum.

Keywords: Citizenship, Citizenship education, Secondary school

\section{Ortaöğretim öğretmenlerinin alg1 ve deneyimlerine göre vatandaşlık eğitimini etkileyen faktörler}

ÖZ Bu araştırmada vatandaşlık eğitimini etkileyen okul, çevre, öğrenci, öğretmen ve program kaynaklı faktörlerin ortaöğretim öğretmenlerinin algılarına ve deneyimlerine göre değerlendirilmesi amaçlanmıştır. Araştırma nitel bir araştırma olup, olgu bilime göre desenlenmiştir. Katılımcılar maksimum çeşitlilik örnekleme göre seçilmiştir. Araştırmanın çalışma grubu 2017-2018 eğitim öğretim yılında Gaziantep ilinin Şahinbey ilçesinde 3 farklı ortaöğretim kurumunda görev yapan 8 coğrafya, tarih ve felsefe öğretmeninden oluşmuştur. Araştırmada veriler yarı yapılandırılmış görüşme formu yoluyla toplanmıştır. Veriler içerik analizi yoluyla analiz edilmiştir. Veriler arasındaki ilişkiler nedensel ağlarla kurulmuş ve gösterilmiştir. Araştırmadan ortaya çıkan sonuçlar katılımcı öğretmenlerin vatandaşlık ve vatandaşlık eğitimi kavramlarını birey, devlet, hak, sorumluluk vb. olmak üzere literatürle benzer kodladıkları görülmektedir. Araştırmada katılımcıların tamamının öğretim süreçlerinde vatandaşlık bilgi ve becerisine yönelik çalışmalar yaptıkları anlaşılmaktadır. Vatandaşlık eğitimi sürecinde öğretim programlarının izlendiği ve informal (plansız) eğitim yoluyla da destek alındığ̣ görülmektedir. Katılımcılara göre vatandaşlık eğitimi üzerinde okul, çevre, öğrenci, öğretmen ve program kaynaklı olumlu ve olumsuz birçok faktör etkilidir.

Anahtar

Sözcükler:

Ortaöğretim, Vatandaşlık, Vatandaşlık ĕgitimi

Citation:

Gürkan, B., \& Doğanay, A., (2020). Factors affecting citizenship education according to perceptions and experiences of secondary-school teachers. Turkish Journal of Education, 9(2), 106-133. DOI: $10.19128 /$ turje. 592720 


\section{INTRODUCTION}

Citizenship education involves not only the qualities of citizenship but also people's perceptions and expectations of the concept, how the topic is managed, and its status in the past, present, and future. In the past, the concept of citizenship was closely related to law-obedient people. Today, however, it is more about educating people to be active participants and raising awareness in terms of responsibility, universal consciousness, empathy, and critical and creative thinking (Acun, Demir, \& Göz, 2010; Kan, 2009). The concept of global citizenship arose due to rapidly developing technology, and the ease of cultural transmission and formation of common universal values (OXFAM, 2015; Penner \& Sanderse, 2017; Schattle, 2008; UNESCO, 2014). The fact that cities are digitalized, and that technology is an everyday part of life leads to the concept of digital citizenship (Ribble, Bailey, \& Ross, 2004; Schuler, 2002). In other words, changes around the world contributed to the concept of citizenship. This study discusses the concept of citizenship in terms of education and the perception of national citizenship. The concept of global citizenship arose from the fact of today's rapidly evolving technology that brings individuals closer together and facilitates intercultural transfer, and the formation of common values upon which people act. Digitalization of cities and the skills and knowledge in the use of technology effectively, ethically, and appropriately constitute the concept of digital citizenship (Ribble et al., 2004; Schuler, 2002). Various definitions have been applied to the concept of citizen based on different aspects, for example national, global, digital, etc. In this study, the notion of citizenship refers to perceptions of national citizenship and education.

\section{Citizenship}

In democratic societies, citizens have the right to participate in governance, enjoy equality before the law and freedom of thought, and have responsibilities such as obeying the law (Doğanay, 2003, p. 17). In this kind of system, the more active the people are in the administration, the better and more efficient the administration is. The definitions of citizenship, in fact, include the role of citizens. Citizenship in the national context is defined in various sources as follows: it is the identity limited to the rules of a piece of Earth that is defined by specific characteristics and on which people have a right to live freely (Ulutaş, 2014); the state establishes a legal status in which it determines the conditions and provisions of the unilateral will and establishes a link between people (Çiftçi, 2006, p. 113); the rights that citizens expect from the state and the rights that the state expects citizens to fulfill (Al-Sabeelah, Alraggad, \& Abou-Ameerh, 2015). Berlach (1996) states that certain groups and individuals are privileged through certain laws and rights, and other individuals or groups may feel weak and deprived of their rights. For this reason, the concept of citizenship changes according to an individual's particular social, economic, ethnic, religious opinions, and values. All in all, citizenship includes political, social, and civil rights and the duties and responsibilities that are expected from citizens. In simple terms, citizenship refers to the relationship between individual and state and the understanding of identity formation.

The concept of citizenship does not only have a political connotation; it has a connotation relevant to daily life as well. Citizenship is not only about the political field, but also about the meaning that individuals give to life at personal, interpersonal, and socio-political levels (Veugelers, 2007). Osborne (1991, p. 24) emphasizes citizenship as an active and not passive concept; Engle and Ochoa (1988, p. 13) argue that, fundamentally, the heart of socialization and democratic citizenship is based on effective decision- making based on knowledge and scientific reasoning. Although individuals are born with the rights and responsibilities of citizenship, citizenship knowledge and skills are learned later and depend on their mental and affective activity. At this point, citizenship should not be considered beyond or above being an individual. On the contrary, the knowledge, skills, attitudes, and competencies acquired throughout life shape active citizenship. Hablemitoğlu and Özmete (2012) state that ensuring continuity 
in a country and combining differences in common points depend on citizenship education. Individuals need to be supported through education in order to gain citizenship characteristics such as thinking, actively participating, producing, and developing. The state undertakes the task of providing citizenship knowledge, skills, values, and attitudes to individuals through formal (planned) education.

\section{Citizenship Education}

Citizenship education involves the teaching of the knowledge, skills, and values required for an individual to be a productive citizen. Burton and May (2015) state that citizenship education is to educate people on the political system/constitution, to encourage participation as voters, to be tolerant of differences, and to prevent political extremism. Kennedy (2012) states that citizenship education can be a policy initiated by the state, a curriculum carried out in a school, a lesson given by a teacher, or an activity of a student; Brooks and Holford (2009) state that citizenship education should be cognitive as well as emotional and social. The sociality of the individual as a social being is necessary for its socialization. Osborne (1991, p. 13) states that schools provide both socialization of the individual and education of citizenship through various courses. He also states that this education is a lifelong, dynamic process. Veugelers (2011) also states that citizenship covers most of life and argues education institutions should give importance to citizenship education, as it contributes to the development of the identity of young people, and, in particular, the hidden curriculum socializes individuals. Sunal and Haas (2002) explain that individuals learn citizenship by interacting and practicing with their groups (pp. 194195). Citizenship is also related to high-level thinking skills. Schools and teachers have significant responsibilities in the acquisition of these skills. Barr, Barth, and Shermis (2013) state that teachers know what needs to be learned and how to feel about what is learned. Akdağ and Taşkaya (2010, p. 93) make suggestions to teachers on video surveillance, projects, and performance assignments, inviting experts to class and creating a discussion environment for the subject of citizenship education. Print and Smith (2000) states that students who learn citizenship in schools as a participant are likely to be active citizens for a democratic society. Remy (1978) states that the development of citizenship in high schools and primary schools is the focus of formal and informal education processes. In this context, it is possible to say that individuals' citizenship development is supported not only by teachers and program factors related to schools but also to their current life outside the school. Torney-Purta, Lehmann, Oswald, and Schulz (2001, p. 21) summarized the factors concerning citizenship education, as present in the model in Figure 1, International Civil and Citizenship Education Study Evaluation Framework.

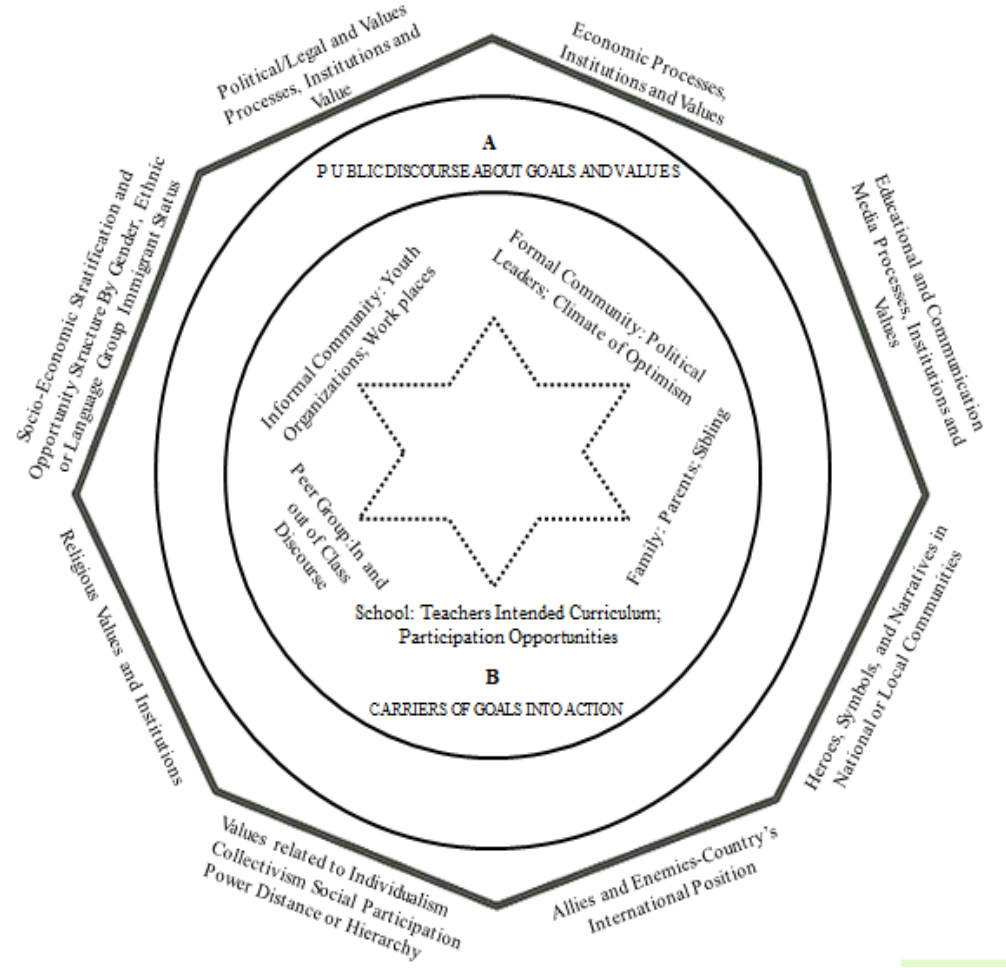

Figure 1. Model for IEA Civic Education Study 
The model suggests that the subject of citizenship education is the individual, who grows with the values and gains of society. In this development process, cases and conditions related to disciplines such as politics, education, economy, sociology, religion, oral literature, international relations, media (communication), and so on are effective. Citizenship gains cannot be independent of the school, teacher, curriculum peer groups (in and out of school), family (parents/sisters), neighbors, immigration, language, gender, or television. As Akdağ and Taşkaya (2010, p. 90) state, in a child's education, family, environment, society, etc. also play as essential a role as school. People also acquire behaviors outside school such as seeking a legal remedy, exercising the right to vote and standing for election and adhering to rules. Similarly, in their research, Biesta, Lawy, and Kelly (2009) emphasize the insufficiency of schools and curriculums regarding citizenship education and the informal (structureless) experiences of young people outside school. Informal education is effective in citizenship education and, therefore, its contribution to this education process should be investigated.

Whether citizenship education should be given as a separate course or should be included in each course has been the subject of discussion. Som and Karataş (2015) argue that citizenship education should be integrated into other courses rather than being given as a separate course. Martin (2010), in his research, concluded that citizenship education could be taught through interdisciplinary or non-interdisciplinary methods in school processes. What is more, he specified in his study that citizenship education is considered valuable in many fields, for example maths, English, science, and social studies. In the secondary curriculum implemented in the 2018-2019 academic year, it was emphasized that there is an integrated approach that is associated with everyday life and different disciplines. Moreover, the curriculum includes eight key competencies that take into consideration the Turkey Qualifications Framework and support the development of knowledge, skill, and values of learners. One of these competencies is the acquisition of citizenship competence in all subjects. Citizenship competence aims to equip individuals with knowledge of social and political concepts in order to participate in civilized life based on democratic and active participation.

Various studies on citizenship education in the national and international literature have been carried out using qualitative, quantitative, and mixed-method approaches in primary, secondary, and higher education levels. There have been studies related to the opinions of the teachers of primary school, social studies or other courses on the application of citizenship education in primary education (Grades 1-8) (Arslan, 2014; Başaran, 2007, Çelik, 2009; Ekici, 2018; Ersoy, 2016; Güven, Tertemiz, \& Bulut, 2009; İkinci, 2016; Özmen, 2011; Öksüz \& Kansu, 2015). Also, there have been studies on the factors affecting the consciousness of citizenship according to the opinions of teachers (Keleş \& Tonga, 2014). Moreover, the literature includes studies on teachers' perception of citizenship education competency (Ülger \& Yel, 2013) and others, for example "The Analysis of Human Rights, Citizenship and Democracy Lessons and Coursebooks" (Er, Ünal, \& Özmen, 2013; Sağlam \& Hayal, 2015; Ünal, 2012) together with studies regarding the opinions of students in the same grade (Misırl1-Özsoy, 2010; Yılmaz, 2013). There are also studies investigating the opinions of high school teachers on citizenship education (Bıçak \& Ereş, 2018); the factors affecting the citizenship perceptions of high school students (Doğanay \& Sarı, 2009); the perceptions of high school students about citizenship education (Dejaeghere \& Hooghe, 2009; K1lınç $\&$ Dere, 2013); the role of geography courses, in active citizenship education (Atasoy \& Koç, 2015) and the perceptions, opinions and competencies of teacher candidates (Acun et al., 2010; Doğanay, 2009; Koutselini, 2008; Martin, 2010; Şimşek, T1kman, Yıldırım, \& Şentürk, 2017; Yiğit, 2017). Moreover, descriptive and comparative studies have been carried out on citizenship education in Greece, Malesia, Canada, the U.K., China, and the USA (Cornbleth, 2010; Evans, 2006; Juanjuan, 2013; Kakos \& Palaiologou, 2014; Mahmood, 2014; Osler \& Starkey, 2006; Pontes, Henn, \& Griffiths, 2019); along with descriptive and comparative studies in Turkey and the USA regarding citizenship education within the scope of social studies (Merey, Karatekin, \& Kuş, 2012).

A review of national and international literature suggests that the notion of citizenship and citizenship training is a universal and recognizable topic that needs to be thoroughly thought through. In the literature citizenship is sometimes limited to a specific course and teachers' opinions are often collected with the use of pre-structured inventories or surveys. Teachers are the practitioners of a pre-determined 
curriculum in the field, and they are expected to keep the curriculum alive. Since teachers are directly exposed to factors affecting citizenship education, it is important to examine the process through their eyes. Citizenship is a lifelong process and only becomes meaningful in education. Citizenship education is accepted as a fundamental goal in history, economics, geography, and other social science courses in high schools (Hoge, 2002). In addition, society, school, family, and student variables should be considered and evaluated together in citizenship education (Uğurlu, 2011). This study therefore contributes not only to the analysis of variables that influence citizenship education such as the environment, the teacher, the students, the school and the curriculum etc. but also to enriching possible educational interventions. This study aims to evaluate the factors affecting citizenship education according to the perceptions and experiences of secondary teachers. The questions posed for this general purpose are as follows:

How do teachers define the concepts of citizenship and citizenship education?

How do teachers provide citizenship competence to their students?

How do teachers explain the positive and negative factors and effects of school, environment, student, teacher, and curriculum on the development of citizenship in their students?

\section{METHODOLOGY}

\section{Research Design}

The research is a qualitative study that is patterned according to the phenomenological method. Phenomenology describes the common meaning of a few people in relation to a phenomenon or concept (Creswell, 2016, p. 77). In this research process, the aim is to reveal the in-depth meaning and nature of experience by focusing on the process of transforming experience into consciousness (Merriam, 2013a, p. 24; Patton, 2014, p.104). This in-depth study emphasizes secondary school teachers' perceptions and experiences of citizenship education. Phenomenological studies concentrate on investigating notions about which we have limited knowledge and, thus, contribute to a better understanding to them. Data sources in phenomenological studies generally tend to be the individuals or groups who have experienced and have been able to transfer the event (Büyüköztürk, Kılıç Çakmak, Akgün, Karadeniz, \& Demirel, 2014, p. 20; Yıldırım \& Şimşek, 2016). The concept of citizenship is associated with being a citizen and shapes the training of citizenship. The teachers that took part in this study who were responsible for citizenship education were asked to share their experiences and perceptions, thus contributing to a deep insight into the factors that potentially influence this training.

\section{Participants}

The participants were eight teachers working in three different secondary schools in the Şahinbey district of Gaziantep province during the spring term of the 2017-2018 academic year. The participants were selected by taking maximum diversity using a purposive sampling method. The key criterion was "The school should have low-middle-high level socio-economic structures, and the teachers should come from different branches and seniority levels". Before the study, Şahinbey District National Education Directorate was approached to obtain the necessary permission. The schools were chosen from different socio-economic levels using the information received from the provincial national education directorate. Participants were volunteers. The participants who work in these schools were teachers of different branches of social sciences. The demographic characteristics of the participants are given in Table 1. 
Table 1.

Data on the demographic characteristics of participants

\begin{tabular}{clllll}
\hline Participant & Gender & Branch & $\begin{array}{c}\text { Years of } \\
\text { service }\end{array}$ & $\begin{array}{c}\text { Type of school and Social } \\
\text { Economic Level (SEL) }\end{array}$ & $\begin{array}{c}\text { The duration of } \\
\text { employment in their } \\
\text { school }\end{array}$ \\
\hline K1 & Male & Geography & 22 years & Anatolian High School-Middle & 4 years \\
K2 & Male & Philosophy & 7 years & Anatolian High School-Middle & 3 years \\
K3 & Male & History & 23 years & Anatolian High School-Middle & 12 years \\
K4 & Female & History & 4 years & Anatolian High School-Upper & 1 year \\
K5 & Male & History & 23 years & Anatolian High School-Low & 10 years \\
K6 & Female & Geography & 22 years & Anatolian High School-Low & 4 years \\
K7 & Male & Philosophy & 26 years & Anatolian High School-Upper & 14 years \\
K8 & Male & Philosophy & 10 years & Anatolian High School-Low & 7 years \\
\hline
\end{tabular}

Two of the participant teachers were female and six males. Three of these teachers were teachers of history, three philosophy, and two geography, and all had worked in at least one and at most four different provinces. In addition, their years of service vary between four and 36 years, and their professional time in their respective schools' range from one to 14 years.

\section{Data Collection Tools}

In phenomenological research, the interview is the primary data collection tool and is used to reveal the underlying structure and reality of experiences (Merriam, 2013a, p. 25). In this study, a semi-structured interview form was prepared by the researchers in order to investigate in-depth perceptions and experiences of citizenship education of teachers working at secondary schools. The semi-structured interview form consisted of two parts. In the first part, items that included participant's demographic information "gender, branch, years of service, provinces they work, the socio-economic level of the school in which they work and their duration of employment in their school" were included. The semistructured interview form that was designed for the study was assessed and revised by three experts in the field, and certain changes were subsequently made. In line with the experts' views, "For you, what is citizenship? was changed to "What do you associate with the notion of citizenship?". The second part consisted of four open-ended questions. The semi-structured interview form was presented to three experts for their opinion. Following feedback from these experts, the questions were presented to two teachers (geography and philosophy teachers) to check their intelligibility and applicability. Following these checks, a semi-structured interview form with four questions was prepared for application.

\section{Data Collection}

Data was collected through interviews in May and June in the 2017-2018 spring semester. A recording device and note-taking were used to collect the data. To prevent data loss, the teachers who did not want to use voice recorders verified their quotations after the interviews. The interviews were conducted in the teachers' lounge or the school guidance office at times when teachers were available, such as during free classes or at the end of their shift. In general, the interviews lasted for 25-30 minutes.

\section{Data Analysis}

The data obtained through interviews was first transferred to computer (Microsoft Office Word). Codes and themes were generated from the data analyzed through content analysis. Themes and codes were determined with by the selective coding method. Lincoln and Guba (1985) state that expert control is the most important method in ensuring the reliability of a study (cited in Creswell \& Miller, 2000). Merriam (2013b, p. 221) also states that a necessary strategy in terms of validity and reliability of a study is to interview colleagues for compliance of the findings with the raw data. In this context, the relevant codes and themes created by the researchers were presented to expert opinion. The coherence rate between the encoders were suggested by Miles and Huberman (1994, p. 64); "P (Percent of Reconciliation $)=[\mathrm{Na}($ Opinion Units $) / \mathrm{Na}($ Opinion Units $)+N d($ Visibility Separation $)] \mathrm{X} 100 "$ was 
calculated with the reliability formula. Codes and themes were studied to determine compatibility between researcher and expert codes, and the fit value between the coders was calculated as $92 \%$. Miles and Huberman (1994, p. 64) state that consensus among coders should be within a range of $90 \%$. In this context, the compliance value is sufficient for reliability. The point on which the researchers disagreed was how some of the codes were expressed. For example, the expression "being a nonchalant citizen" was changed to "being unconcerned about citizenship education", as agreed.

Causal networks within the findings of the study were identified. Causal networks are networks that illustrate the causal connections between variables derived from multi-case analysis (Miles \& Huberman, 1994, p. 209). For drawing the causal networks in the research, Microsoft Office PowerPoint software was used. In addition, each finding was supported with direct quotations, and the symbol " $\mathrm{K}$ " was used for the participants (e.g., K1, K2...K8, etc.). In the quotations, the participant code, the interview date, and the meeting place were given, for example [K2, 09.05.2018, Guidance Office].

Creswell (2012) states that researchers should be aware of any ethical problems that may arise in qualitative research and that various methods should be developed for these problems. In this study, the required permission was obtained from the Gaziantep Provincial Directorate of National Education for the schools where the study was to be carried out. Before the interviews, teachers were given a receipt of permission, in which the purpose of the study was explained. Interviews were conducted in places where teachers could express themselves comfortably (the teachers' lounge or guidance office). The data that was noted after each interview was read to the teachers. Also, raw data and findings obtained from the research were stored on computer.

\section{FINDINGS}

This study aimed to examine the citizenship education process in depth according to the opinions of eight secondary school teachers. The findings are presented below in order according to the subobjectives of the research.

\section{Concept Perceptions and Teaching Experiences}

According to the participants, the concept of citizenship is divided into two themes: the individual and state. For the participants, the concept of citizenship is individual-based to which they gave different meanings. Participants [K1, K2, K5, K6, K7] perceived the concept of citizenship as knowing the rights of citizenship; [K4, K8] perceived it as a legal status and identity; [K1, K4] perceived it as the awareness of citizenship responsibility; [K4, K6] perceived it as being a member of a state; [K3, K7] perceived it as having legal responsibilities; and [K1] perceived it as fulfilling the duties of citizenship. The theme of 'state' revealed that only the teachers [K4] expressed the concept of citizenship as the responsibility of the state to the individual. The quotations for these views are given below:

"Citizenship is having rights defined by the laws of the country where the borders are located. Citizenship education is the transfer of information about rights, duties, and responsibilities in the law through schools. First of all, I am trying to make them aware of the rights that the constitution gives us. During the lessons, we talk about tasks against one's self, family, environment, and state." [KI, 09.05.2018, Teachers' Lounge]

"The individual has responsibilities towards the state, just as the state has responsibilities towards each individual. It can also be described as being a member of a state, and therefore having a status that includes certain legal title and provisions" [K4, 16.05.2018, Teachers' Lounge] 
The participants' answers regarding what constitutes the concept of citizenship education were classified into three themes: individual, state, and state and individual. Their answers revealed that they perceive citizenship education in the context of the state. In this context, [K5, K7] perceive the concept of citizenship education as raising citizenship awareness; [K4] perceives it as raising awareness of national values; [K6] perceives it as forming a sense of belongingness; [K6, K8] perceive it as the acquisition of beneficial behavior. The individual context theme showed that participants [K1, K2, K3, K4, K7] saw citizenship education as rights and responsibility education; participant [K6] thinks that the individual develops respect for himself and his state. The following is one of the participants' views on these findings:

"To be able to teach individuals about belonging to the state. To exhibit useful behavior for the sake of the state. I think it is both teaching self-respect and teaching individuals to respect their country. Citizenship education. Uhmm, I think it is education about making individuals realize their rights and responsibilities towards the state as a citizen..." [K2, 09.05.2018, Guidance Office]

In the study, the participants were asked about their experiences of citizenship education, and all teachers explained with examples that they were working on citizenship knowledge and skills in teaching processes. Three of the participants [K1, K3, K6] carried out citizenship education according to the content of the curriculum; another three participants [K2, K7, K8] performed interdisciplinary education and one participant [K5] carried out citizenship education through formal and informal education. In addition, one participant [K4] stated that citizenship education is realized through latent learning. Exemplary teaching of participants' experiences in citizenship education is given in the following quotations:

"However, as the occasion arises, we convey the beauty of our country and its strategic geopolitical position in the world. In addition, patriotism is conveyed from time to time with questions and answers within the subjects of citizenship consciousness." [K1, 09.05.2018, Teachers' Lounge]

"I tell students the requirements and responsibilities of being a human in a general context and of being a citizen in Turkey in Democracy and Human Rights courses. Explaining the subject in the related fields of the Philosophy and Sociology course, I increase the perception of students about citizenship through examples." [K2, 01.06.2018, Guidance Office]

\section{Factors Affecting Citizenship Development}

In the present study, the positive and negative effects of participants' opinions regarding factors such as school, environment, student, teacher, and curriculum on citizenship education were emphasized. The findings obtained for this sub-purpose are presented through causal relationships.

\section{School-Oriented Factors Affecting Citizenship Development}

In the study, positive and negative factors affecting the development of citizenship and arising from the school environment were examined according to the participants' views. Relevant findings are presented in Figure 2 and Figure 3. 


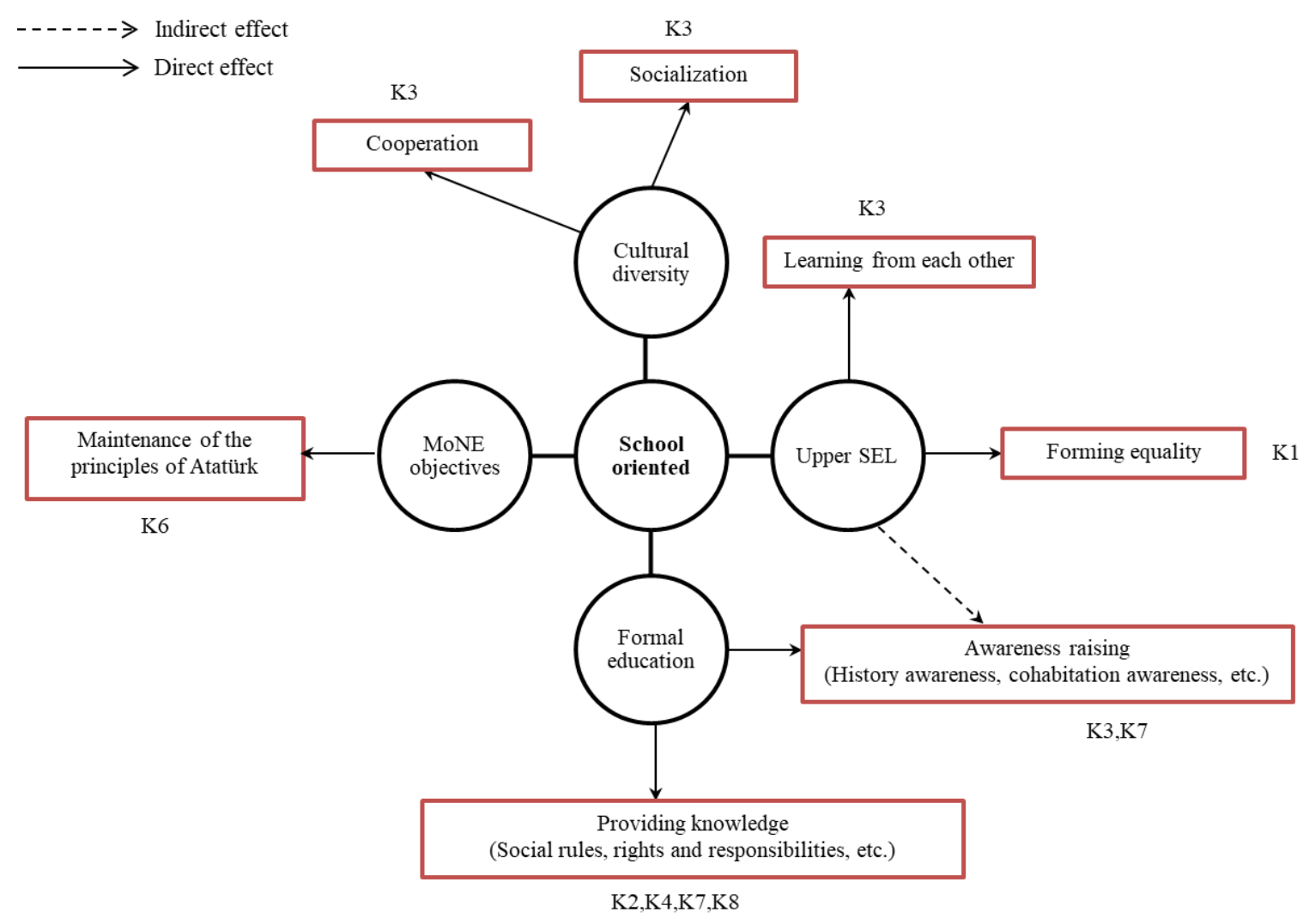

Figure 2. Causal network related to positive school-based factors affecting citizenship development

The participants see the multicultural atmosphere of the school environment, the upper socio-economic level of the school, the objectives of the Ministry of National Education, and formal (planned) education as positive factors affecting citizenship education. Participant [K1] mentioned the positive effects of the multicultural structure of the school in promoting socialization and cooperation. Participant [K6] pointed to the positive effects of the maintenance of the principles of Atatürk by the Ministry of National Education (MoNE).

Participants [K2, K4, K7, K8] consider the knowledge provided by informal education as a positive factor affecting citizenship education, while participants [K3, K7] consider awareness raised in the formal education as a positive factor affecting the citizenship education. The following criteria were specified as positive factors supporting citizenship development: equality among students due to upper socio-economic level [K1], the fact that students know each other well [K3], and that the school raises students' awareness [K3, K7]. The following are some of the participants' views on these findings:

"All colors of society coexist in a school. Socialization, awareness, cooperation, and historical awareness are provided." [K3,11.05.2018, Teachers' Lounge]

"Courses have a positive effect on citizenship consciousness. The development of the socio-economic environment of the school positively affects the consciousness of citizenship, because students who study at schools in an economically and socially developed environment are conscious individuals." [K7,16.05.2018, Teachers' Lounge] 


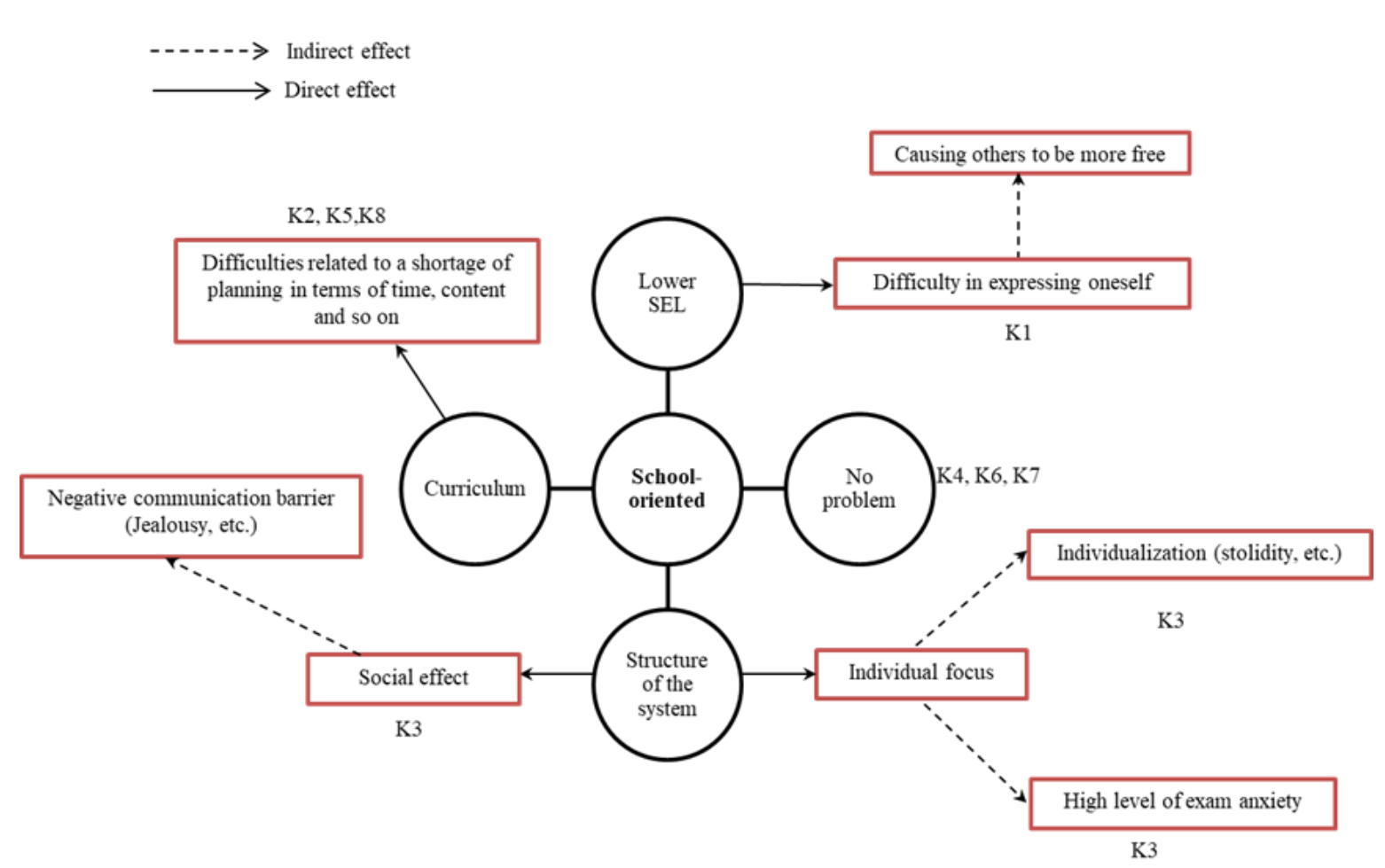

Figure 3. Causal network related to negative school-based factors affecting citizenship development

The participants' responses regarding the school-oriented factors that negatively affect citizenship education were categorized under the themes of curriculum, system structure, and lower socio-economic level. Participants [K4, K6, K7] believe that there are no factors in which the school adversely affects citizenship education. One of the participant teachers [K1] states that students studying at low socioeconomic level schools have difficulty in expressing themselves, and this situation has caused others to be freer, which is one of the school-oriented negative reasons. Three participants [K2, K5, K8] think that where there are difficulties related to a shortage of planning in terms of time, content, and so on adversely affect citizenship education. In addition to these findings, one participant [K3] believes that the education system causes students to individualize, to have a high level of exam anxiety, and to have negative communication among themselves (jealousy, etc.), which are considered negative factors. The participants' opinions on these situations are as follows:

"Socio-economic subculture, the economic structure of disadvantaged groups cannot express themselves well. These people constitute free environment by pulling themselves back" [K1, 09.05.2018, Teachers' Lounge]

"There are also systemic reasons. Wrong examples, test anxiety, selfishness, self-interest, note-centered individualization, and indifference lead to jealousy." [K3,11.05.2018, Teachers' Lounge]

\section{Environmental Factors Affecting Citizenship Development}

In the study, positive and negative factors that affect citizenship development were examined according to the participants' views. The findings of this sub-objective are presented in Figure 4 and Figure 5. 


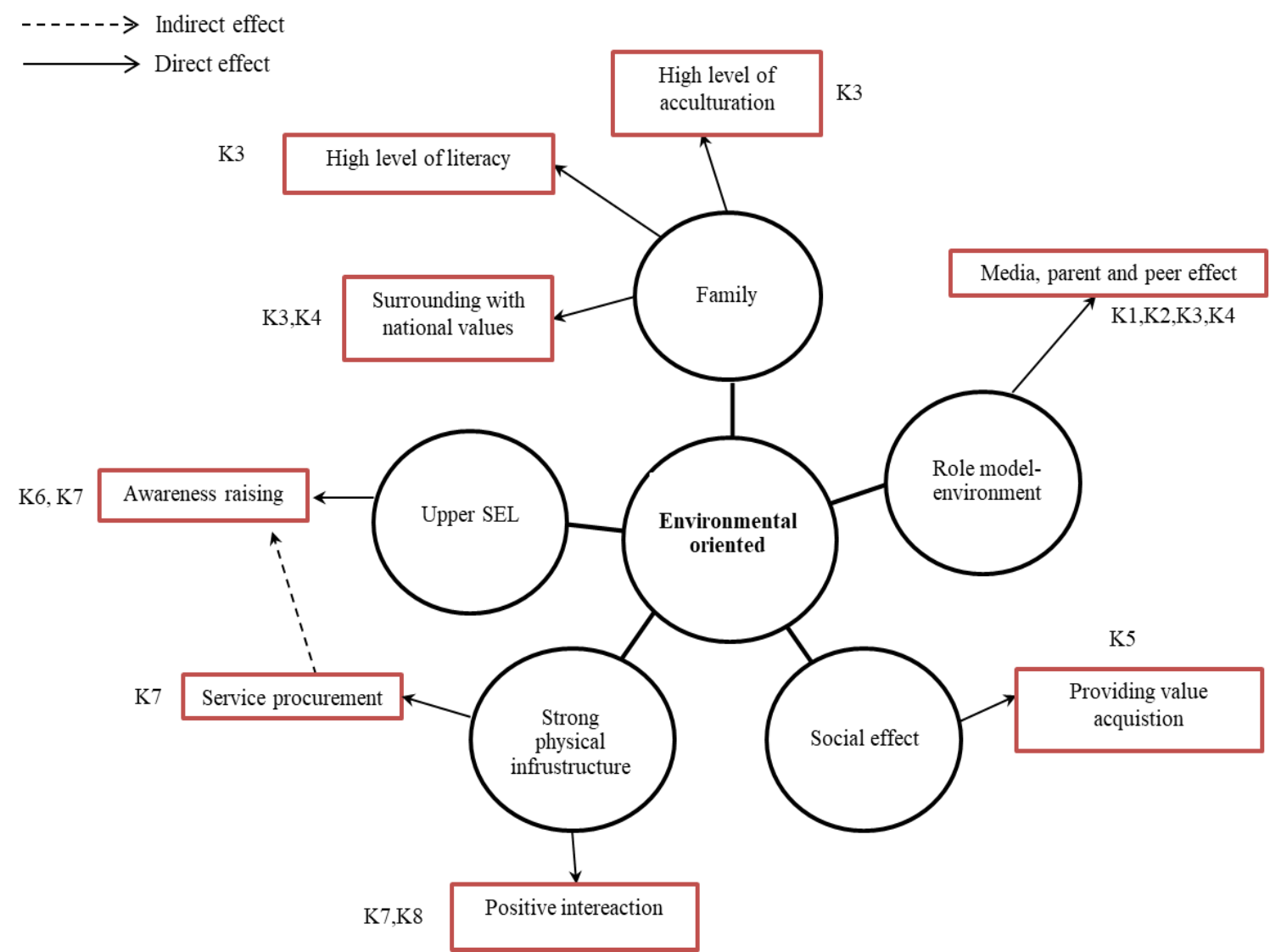

Figure 4. Causal network related to positive environmental factors affecting citizenship development

Participants think that family, role models, environment, upper socio-economic level, strong physical infrastructure, and social impact have a positive effect on citizenship education. Several of the participants believe that the high acculturalization of the family [K3], sufficient literacy level [K3], and being surrounded by national values [K3, K4] have a positive effect on citizenship education.

Participants [K1, K2, K3, K4] refer to the importance of role models in the media, parents, friends, etc. and participant [K5] believes in the role of the society. Participants [K6, K7] believe that the upper socio-economic level and the strong physical infrastructure also benefit individuals' awareness. Participants [K6, K7] believed that an upper socio-economic level and strong physical substructure also benefit individuals' awareness. Particularly in this context, participant [K7] believes that people can become conscious of the services they will get from a strong physical infrastructure, while participants $[\mathrm{K} 4, \mathrm{~K} 6, \mathrm{~K} 7]$ think that it makes interaction between individuals more positive. The following are some of the participants' views on these findings:

"Individuals such as teachers and siblings can have a positive impact on students. In adolescence, TV series, artists, mothers, fathers, relatives can leave more lasting effects on the students. [K1, 09.05.2018, Teachers' Lounge]

"The environment is an important factor in raising the awareness of the individual about citizenship. A good environment means a good citizen. The family and the environment of the individual provide for the shaping of citizenship. Having a family with national values means raising a good citizen, a responsible individual. Young people are more affected by their environment. The family and environment have the greatest effect on shaping the person. [K4,16.05.2018, Teachers' Lounge] 


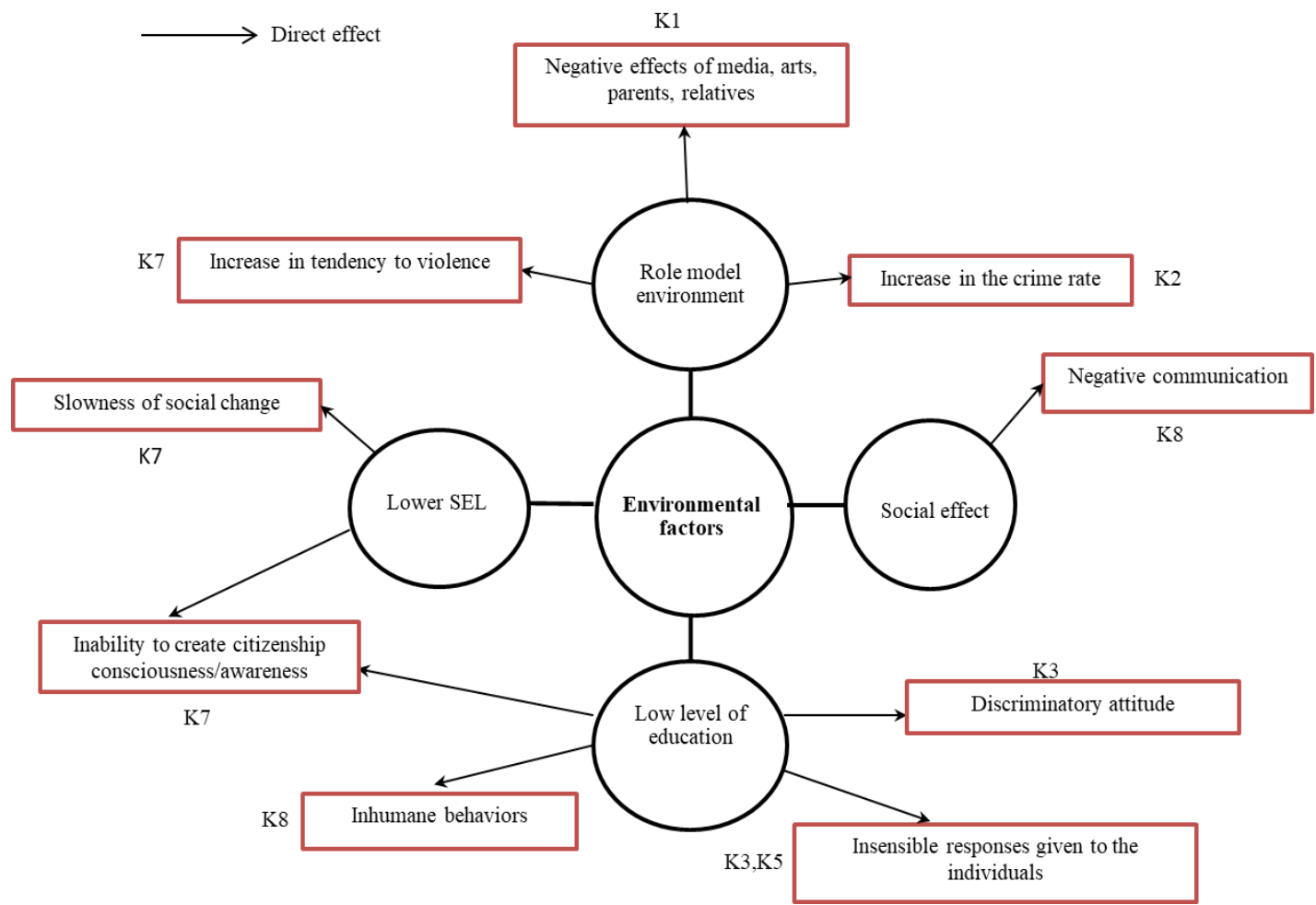

Figure 5. Causal network related to negative environmental factors affecting citizenship development

Participants think that environmental factors such as role models, environment, low socio-economic level, low education level and social effect have a negative impact on citizenship education. Among the participants, some think that an increase in the tendency to become violent [K7], negative effects of media, arts, parents, relatives [K1], etc. and the increase in crime rate [K2] affect citizenship education adversely. Negative communication between individuals in the living environment [K8], the slowness of social change caused by a low socio-economic condition of the environment [K7], and the lack of citizenship consciousness [K7] are thought to affect the development of citizenship adversely. In addition, among the negative effects, the following factors were mentioned: low education level of the environment creates a destructive, discriminatory attitude [K3], insensible responses given to individuals [K3, K5], the inability to create citizenship consciousness [K7] and inhumane behavior [K8]. The participants' views on this point are as follows:

"It is easier for citizens who grow up in a negative environment to be involved in crime. As a social citizen, every individual is very easily affected by the environment. [K2, 01.06.2018, Guidance Office]

"People have a lack of knowledge of citizenship and sometimes exhibit negative behaviors that are incompatible with citizenship and humanity, and thus can be a bad example. [K8,01.06.2018, Teachers' Lounge]

\section{Student-Oriented Factors Affecting Citizenship Development}

In the study, the positive and negative student-oriented factors that affect the development of citizenship were examined according to the participant views. Relevant findings are presented in Figure 6 and Figure 7. 


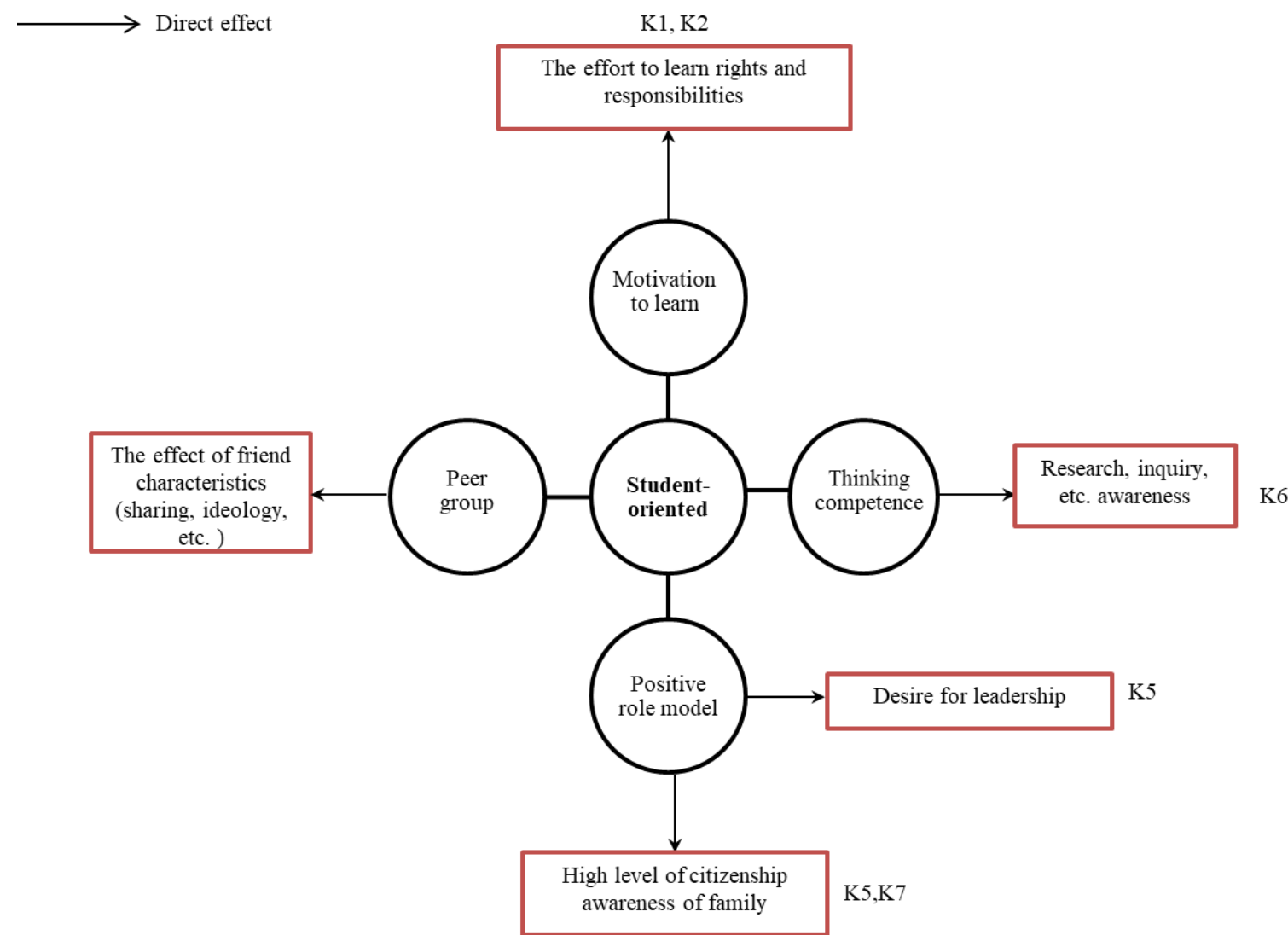

Figure 6. Causal network related to positive student-oriented factors affecting citizenship development

Participants stated that factors such as the desire to learn, positive role-modeling, peer characteristics, and competence in thinking have a positive effect on students' citizenship education. For participants [K1, K2], if students make an effort to learn their rights and responsibilities and, for participant [K6], if students have research, inquiry awareness, these students' citizenship education is positively affected. It is also thought that students' leadership desire [K5] and a high awareness of citizenship within the family $[\mathrm{K} 5, \mathrm{~K} 7]$ are a positive role model for students. In addition, participants [K3, K4, K6, K8] believe that peer-sharing during high school lead to positive gains in citizenship development. Below are the opinions of participants K4 and K6:

"If the student group is well-educated, the student becomes more likely to be a good citizen. The ideology and perspective of the group in which the student is involved substantially affect the individuals at high school age. If the group has good values and citizenship consciousness, the individual can also gain this value. Peer pressure is effective for students because young people are open to being affected by age." [K4,16.05.2018, Teachers' Loung]

"An investigating student is a student who asks for his/her rights. Usually, the social circle has a positive impact on students. A nice behavior exhibited by peers is accepted easily."[K6,01.06.2018, Guidance Office] 


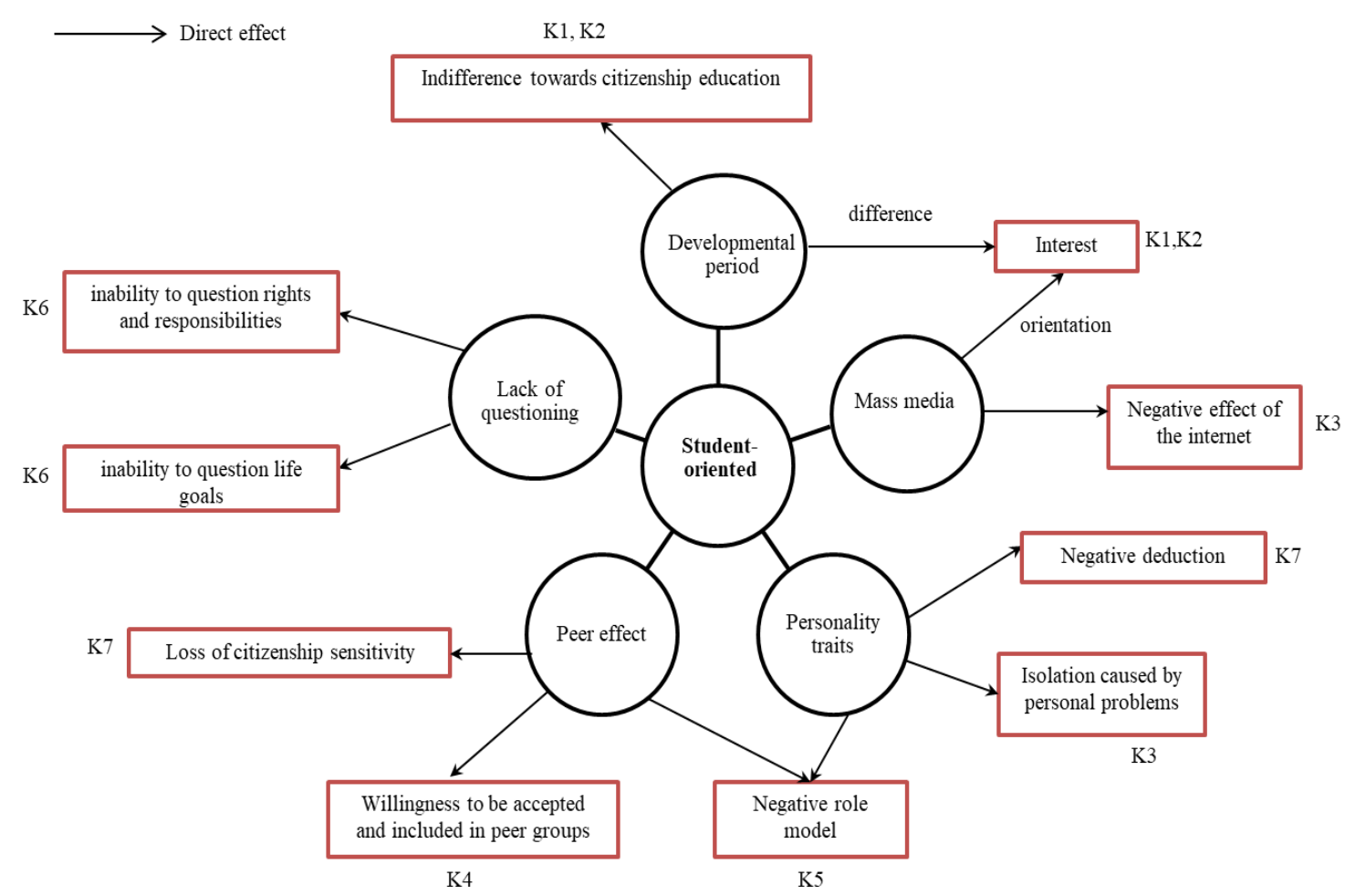

Figure 7. Causal network related to negative student-oriented factors affecting citizenship development

In the study, negative factors stemming from the students affecting citizenship education were collected within the context of the developmental period, mass media, personality traits, peer effect, and lack of questioning. Participant [K6] considers students' inability to question life goals, rights, and responsibilities is a negative factor. Participants [K1, K2] consider students' insensitivity and interest in different directions as characteristics of developmental periods and think that this is an obstacle to the development of citizenship. It is believed that the negative effect of the orientation of the mass media $[\mathrm{K} 1, \mathrm{~K} 2]$ and the internet [K3] have negative effects on students.

Students' negative role models in terms of their personality traits [K5], tendency to make negative inferences [K7], and isolation caused by personal problems [K3] suggest that citizenship education is not a desired quality. One of the findings of the study is that the loss of citizenship sensitivity [K7], students' willingness to be accepted and included in peer groups [K4], and negative role modeling [K5] are negative effects of peers on the development of citizenship. The views of participants K3 and K4 are as follows:

"The type of student who is lonely, irresponsible, and troubled with idle attitudes sets a bad example. Very fast popularization and encouragement of bad examples such as internet environment... "[K3,11.05.2018, Teachers' Lounge]

"Students often start bad behavior due to malicious groups of friends. Involvement in a group that does not know its responsibilities completely attracts individuals to this negativity. Peers are more effective than family members for students. Fear of rejection and desire to be included in the group due to age."[K4,16.05.2018, Teachers' Lounge]

\section{Teacher-Oriented Factors Affecting Citizenship Development}

In the study, positive and negative teacher-oriented factors that affect the development of citizenship were examined according to the participant's views, and their findings are given in Figure 8 and Figure 9 , respectively. 


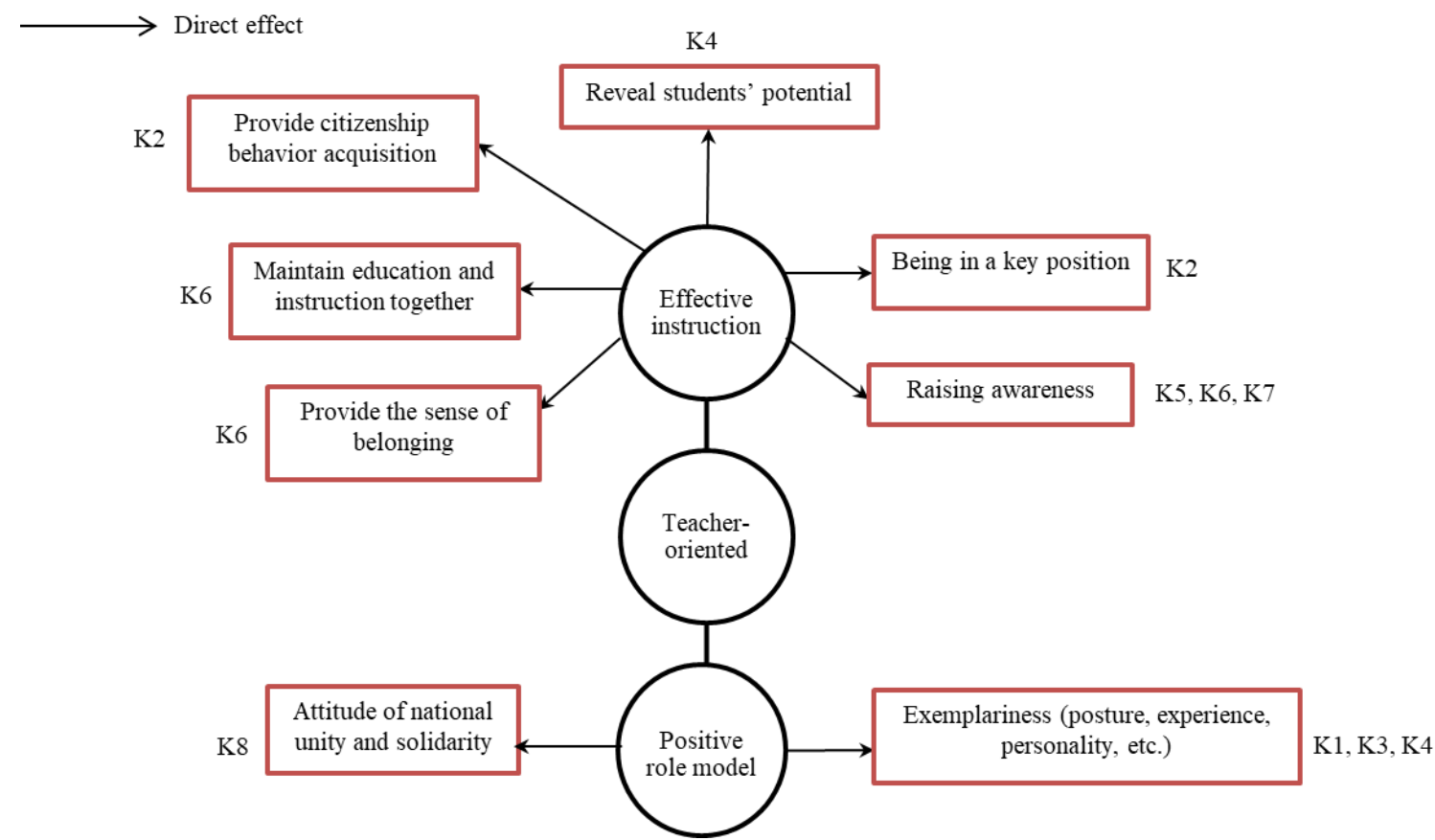

Figure 8. Causal network related to positive teacher-oriented factors affecting citizenship development

Teacher-oriented factors that positively affect the development of citizenship are grouped in the theme of effective teaching and positive role model. Participant [K2] perceives teachers being in a key position to encourage the acquisition of citizenship behavior as a positive factor in an effective teaching context. In addition, in this context, a teachers' ability to help a student reach their potential [K4], to maintain unity of education and instruction [K6], to provide students with a sense of belonging [K6] and to raise awareness [K5, K6, K7] is considered positive in terms of citizenship education. It is also believed that teachers' positive attitudes in the context of being a role model of the characteristics of national unity/solidarity attitudes [K8] and setting an example (posture, experience, personality, etc.) [K1, K3, $\mathrm{K} 4]$. Below are the opinions of participants $\mathrm{K} 4$ and K8:

"A teacher who is a good citizen educates students to exhibit positive behavior. The students usually take their teachers as role models. Teaching is already the art of revealing the power of the individual. [K4,16.05.2018, Teachers' Lounge]

"Their emphasis on national unity and solidarity and setting an example with their behavior. Contributing to the subject with their commitment to national values by exhibiting an exemplary identity and personality." [K8,01.06.2018, Teachers' Lounge] 


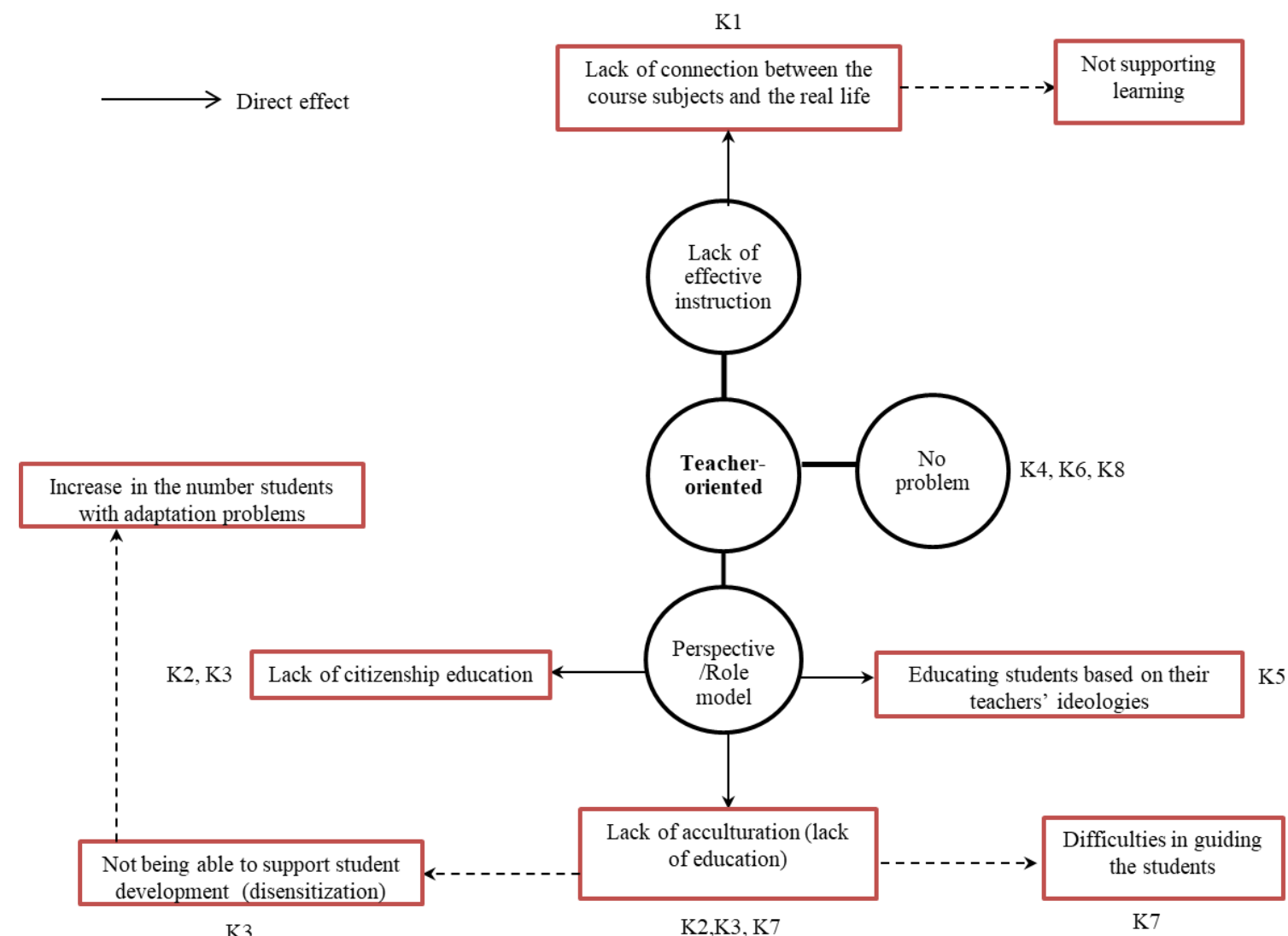

Figure 9. Causal network related to negative teacher-oriented factors affecting citizenship development

In the research, teacher-oriented factors that affect the development of citizenship negatively are grouped in effective teaching and positive role model themes. Three participants $[\mathrm{K} 4, \mathrm{~K} 6, \mathrm{~K} 8]$ think that teachers do not cause any negative effect. Looking at the theme of effective teaching, participant [K1] thinks that learning is not supported in a positive way when teachers cannot establish a connection between their course subject and real life. The perspective/role model theme revealed that if teachers educate students based on their own ideology [K5]; if there are deficiencies in acculturation [K2, K3, $\mathrm{K} 7]$; if citizenship education is insufficient [K2, K3] problems such as difficulties in guiding students [K7] and adaptation among young people [K3] may occur. Below are the views of the participants K1 and $\mathrm{K} 7$ :

"The teacher should involve daily life while explaining subjects. This is a general problem of our national education system. Students are more interested in the subjects that are based on true events "[K1, 09.05.2018, Teachers' Lounge]

"The fact that the teacher does not have sufficient knowledge on this subject affects the students adversely, and the teacher is inadequate in guiding students. " [K7,16.05.2018, Teachers' Lounge]

\section{Curriculum-Oriented Factors Affecting the Development of Citizenship}

The positive and negative curriculum-oriented factors affecting the development of citizenship were examined through the views of the participants. The related findings are presented in Figure 10 and Figure 11: 


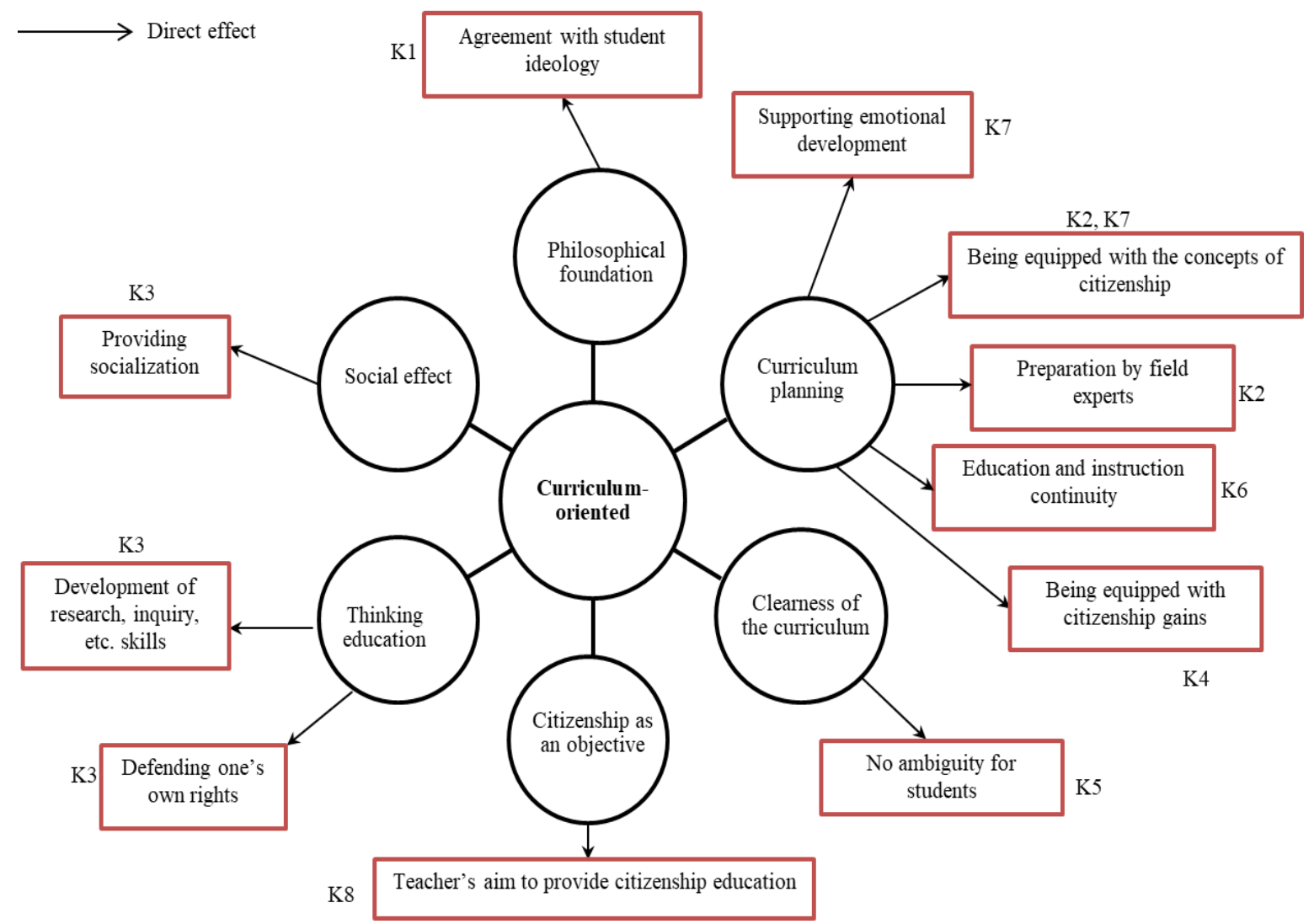

Figure 10. Causal network related to positive curriculum-oriented factors affecting citizenship development

It is noteworthy that the participants in the research gave more explanations about the curriculum. It is observed that the curriculum-oriented factors that positively affect citizenship education are grouped in the themes of a philosophical basis, planning of the curriculum, clarity of the curriculum, citizenship as a goal, thinking education, and social impact. The factors that affect the citizenship education positively are as follow: the agreement between the philosophy of the curriculum and student ideology [K1]; the social effect of the curriculum and the fact that the curriculum develops students' research and inquiry skills together with the skill of defending one's rights [K3]; curriculum and the teachers aim to provide citizenship education [K8]; curriculum is clearly understood without confusion from students [K5]. Looking at participants' views, it is believed that features of the curriculum such as supporting emotional development as part of the curriculum planning [K7]; being equipped with the concepts of citizenship [K2, K7]; being equipped with citizenship gains [K4]; preparation by field experts [K2]; education and teaching continuity [K4] have positive effects on the development of citizenship. Some participants' views on this are given below:

"Citizenship awareness is established by the concepts and activities in a well-prepared curriculum determined and prepared by the experts in the field." [K2, 01.06.2018, Guidance Office]

"Success is gained if the idea is short, concise, and understandable, because young people do not enjoy long and meaningless expressions." [K5,01.06.2018, Teachers' Lounge] 


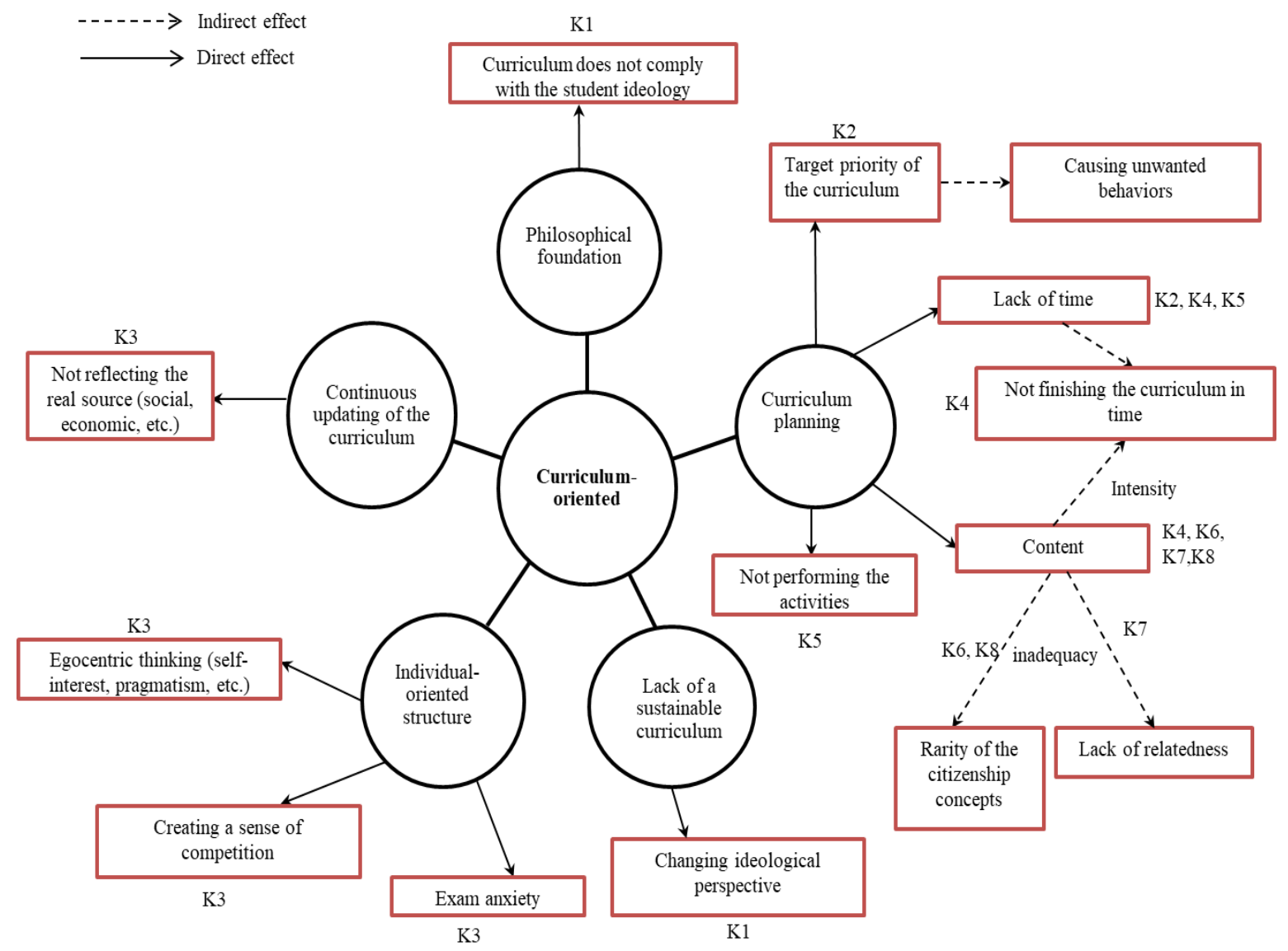

Figure 11. Causal network related to negative curriculum-oriented factors affecting citizenship development

In the research, it is noteworthy that the participants attributed a negative meaning to the curriculum for affecting citizenship education. The curriculum-oriented factors that adversely affect the development of citizenship are grouped in the themes of philosophical foundation, planning of the curriculum, lack of a sustainable curriculum, individual-oriented structure, and continuous updating of the curriculum. Participant [K3] thinks that a constantly updated curriculum cannot provide students' social, economic, etc. needs and that the curriculum creates a sense of competition among students because it is individualoriented and it encourages students' egocentric thinking and test anxiety.

Participant [K1] states that the development of citizenship is also negatively affected when the philosophy of the curriculum does not comply with student ideology. Participant [K1] states that the ideological perspective has changed since the curriculum is not sustainable, and this has a negative effect on students. The theme of curriculum planning reveals that errors in the target priority of the curriculum cause unwanted behaviors [K2]; the inability to process activities [K5] and lack of time [K2, K4, K5] negatively affect citizenship education by preventing finishing the curriculum in time. Moreover, the rarity of citizenship concepts [K6, K8] and lack of relatedness [K7] was mentioned as negative effects of curriculum content. In addition, participant [K4] states that due to the amount of content, it is not always possible to finish the curriculum in time, which is a negative factor in citizenship development. Some participants' opinions are presented below:

"Knowingly or unknowingly, providing citizenship values in school, lessons and social activities in the background..." [K6,01.06.2018, Guidance Office]

"Since the curriculum is theoretical, it can be difficult for students to connect it with social life." [K7,16.05.2018, Teachers' Lounge] 


\section{DISCUSSION AND CONCLUSION}

Individuals can become members of a nation or a state from the moment they are born and live with the rights and responsibilities of life-long citizenship. Individuals learn the desired characteristics of citizenship through planned or random training. Brooks and Holford (2009) state that learning citizenship should be emotional and social as well as involving identity and action dimensions. With citizenship education, individuals should gain knowledge about various political concepts, citizenship rights and responsibilities, national and global problems (Ersoy, 2016). The main objective of citizenship education is to educate individuals to be democratic, knowledgeable, and critical thinking citizens who can actively participate in civilian life and state affairs (Schugurensky \& Myers, 2003). It is quite important to know how citizenship education is done in the formal context and which dynamics are affected by this process. This study aimed to examine the positive and negative factors affecting citizenship education in high school education according to the opinions of secondary school teachers.

Martin (2008) stated that it is important to determine the citizenship perceptions of primary and secondary school teachers who will play a role in the education of future generations. This study examined the concept of citizenship and citizenship education believing that the perception of situations, events, objects, and concepts affects teachers' education/teaching processes. In the literature, citizenship is generally seen as a link between the individual and the state, and the legal status provided to the individual and the rights and responsibilities of the individual in the context of this status (Engle \& Ochoa, 1988). Veldhuis (1997) states that citizenship includes a civil dimension such as individual freedoms, a political dimension related to political rights and duties, a social and cultural dimension including social relations and common cultural heritage, and an economic dimension relating to production and consumption activities.

The findings of this study reveal that participants conceptualize citizenship in the shape of knowing citizenship rights and responsibilities and acquiring status and identity. Yiğit (2017) examined the concepts of citizenship and Turkish citizenship from the perspective of teacher candidates in the field of social studies. He determined that teacher candidates make sense of citizenship concepts in the context of rights and responsibilities. In their study conducted to examine citizenship education according to social sciences and primary school teacher candidates, Şimşek et al. (2017) found that candidates code the concept of citizenship on themes of belonging, rights, law, duty, responsibility, loyalty, freedom, and so on. Similarly, in his study with prospective teachers, Koutselini (2008) specified that citizenship is defined using words like duty, active interaction, and so on. In this study, participants explain citizenship education in the shape of citizenship awareness training, education of rights and responsibilities, national values and gaining a sense of belongingness to the state, and so on. In the study conducted by Kondu and Sakar (2013), teachers think that citizenship education is related to the responsibility to become citizens, basic rights and freedoms, values education, and so on. In this context, it can be said that the meanings attributed by the participants to the concepts of citizenship and citizenship education coincide with the definitions of the concept in the literature, and they are similar to those of different research findings.

Som and Karataş (2015) state that students should participate actively in the process of citizenship education, and teaching methods should be employed together with knowledge, skills, and values, and the curriculum should be prepared in this context. In this study, all the participants had conducted studies on citizenship knowledge and skills in the teaching processes, and took into account the content of the curriculum. They were involved in interdisciplinary education and carried out informal (unplanned) citizenship education. Similarly, Güven's (2002) study concluded that teachers handle citizenship activities with an interdisciplinary approach. Citizenship education requires the co-operation of theory and practice. Active participation is the most important act of citizenship education. Individuals can learn citizenship if they exist in social, political, economic, cultural, etc. contexts. Citizenship education requires learning beyond the boundaries of formal (planned) learning with schools, teachers, students, 
managers, and other participants (Uğurlu, 2011). Torney-Purta (2002) states that schools have the most public space in which young people spend the majority of their time from the age of 6 to 17 and that teachers are in a unique position to shape citizenship knowledge, attitudes, and behavior. In his study examining the views of social studies teachers about the current situation and future of citizenship education, Çelik (2009) states that teachers think family, friends' groups, television, print media, the internet, etc. are necessary for citizenship education. In the process of citizenship education, Ersoy (2016) states that teachers need to cooperate with family, school, and also institutions and organizations around the school. In this study, citizenship education of young people is examined within the context of schools, teachers, students, environment, and program contexts, and it has been revealed that citizenship education is affected by many positive and negative factors. Participants view the multicultural structure of the school, the formal (planned) education process, and the tendency of the Ministry of Education to keep alive principles of Atatürk as positive factors affecting citizenship education. Stressing the importance of multicultural education, Seiger (1996) says that students should acquire values and skills in a national and universal context for citizenship education. Participants believe that the tendency of the general education system to emphasize individuality and create anxiety in individuals is a negative factor. In their study examining the factors affecting citizenship awareness of the students, Keleş and Tonga (2014) state that teachers think that the exam system creates academic concerns for students, and this also affects citizenship development adversely. Similarly, Güven (2010) states that teachers experience problems in educating effective citizens and that the exams are a matter of concern; according to the teachers in Wilkins's (2003) study, the exam system affects citizenship education adversely. An exam-based education system means the majority of students' time is spent in preparation for exams. In this process, it is possible to say that students exhibiting antisocial behavior, exhibiting concerns about the future, and failing to prioritize the duties and responsibilities of active citizenship may be natural.

Another factor relevant to the effect of school and environment on citizenship education is socioeconomic level. Participants in upper socio-economic level schools think that economic prosperity affects citizenship education positively; participants in lower socio-economic level schools think that economic problems affect citizenship education negatively. Uydaş and Genç (2015), in their study examining the views of secondary school students about multiculturalism in the context of global citizenship, concluded that students with low socio-economic status are less aware of citizenship rights compared to the students with moderate socio-economic status. Güven (2010) states in this study that teachers think that citizenship consciousness is affected by socio-economic level. All these findings show that the socio-economic situation, which is one of the important inputs in meeting people's basic needs, and the provision of various services have an impact on citizenship education.

Another striking point in the study is the views of participants on family roles in citizenship education. Families with high levels of literacy, cultural awareness and possess national values have a positive impact on citizenship education. Stuen (1996) states that teachers view the family as the most important factor in shaping beliefs about citizenship. Güven, Tertemiz, and Bulut (2009) found that the family was an important factor in the formation of citizenship consciousness. Similarly, Doğanay and Sarı (2009) state that the level of family income, education level and interest in politics had an impact on the citizenship perceptions of high school students; Keleş and Tonga (2014) determined that the education level of families and their attention to citizenship were considered important in terms of citizenship education. All these research findings show that the family is important in citizenship education. The family is the first institution where the individual begins to receive an education. Individuals develop surrounded by the behavior of their parents and siblings, etc., they imitate what they see and develop particular reactions. In this context, it is possible to say that the principles of child-rearing, the level of parents' culture, and their sensitivity towards humanity and the environment have a great impact on citizenship education.

Engin and Sarsar (2015) state that with the use of social media sites such as Facebook, Twitter, YouTube, etc., young people can be expected to be aware of world diplomatic, social, and political events. In this study, the participants stated that media, mass media, and the internet have an important 
effect on citizenship education. According to the participants, these tools direct students' interests and create positive or negative role models for them. Yigit (2017) states that teacher candidates see tools such as social media, the internet, and so on as a source of information for citizenship education, and they believe that these tools can contribute to individuals as active citizens and can affect individuals. Both research findings show that social media and mass media have an important role in citizenship education. Today, young people participate in the political, social, economic, etc. arena through social media. More importantly, to continue to benefit from social media, it is important young people gain knowledge and skills in media literacy from an early age. In the study, participants made positive evaluations for the environment context because of the strong physical infrastructure, facilitating services, and improving interactions among individuals. However, participants claim that a tendency toward violence in the environment increases the crime rate; a destructive/discriminatory attitude and lack of communication badly affect citizens' perception and actions.

Balkaya and Ceyhan (2007) found in their study that the majority of high school students had a sense of identity at a moderate level and that students' level of sense of identity acquisition was negatively correlated with the level of criminal behavior. The period in which young people attend high school includes their adolescence, when young people search for identity and change rapidly in terms of physical, psychosocial, and cognitive aspects. During adolescence, young people seek answers to the question "Who am I?" (Morsünbül \& Çok, 2013). Citizenship education has a special place and importance in terms of high school education level because during this period, young people can think critically and participate directly in active citizenship processes. In the study, participants consider the personality and development characteristics of students as important in terms of acquiring citizenship knowledge, attitudes, values, and skills. Participants think that students with good thinking ability, research/inquiry, etc., and whom are members of families with a high level of citizenship perception and consciousness have a positive citizenship education. However, the participants believe that students who are not aware of their rights and responsibilities and who cannot determine the purpose of life do not do well in citizenship education. In addition, it is perceived as normal for young people to be insensitive to citizenship education or to be interested in different things due to their age, but these are considered negative for citizenship education. Learning is an individual activity, and many external and internal stimuli influence it. When the research findings are examined, intrinsic factors such as personality traits, development period, etc. have an affects citizenship education.

A strong factor that draws attention to citizenship education is the positive and negative effects of peer groups on attitudes and actions. Participants believe that students in this age group are very much influenced by their peers. They exhibit certain desires and tendencies, such as self-acceptance. Adolescents trying to gain prestige and status in society seek the people they want to be like and go on to regulate their activities in accordance with them (Şahin \& Çövener Özçelik, 2016). For this reason, it is thought that any kind of sharing between peer groups can affect individuals positively or negatively.

The role and responsibilities of teachers in citizenship education are very strong. In their research, Torney-Purta, Richardson, and Barber (2005) state that teachers' knowledge and experience about citizenship affect students' citizenship competencies. In the present study, according to the participants, teachers make positive contributions to the citizenship education of students by setting a good example, being a role model, making use of their experiences, and effective teaching qualifications. If teachers cannot teach effectively and train individuals according to their ideology, they are thought to affect their students badly. Furthermore, if teachers' citizenship knowledge and skills are insufficient, the students' learning is negatively affected. Şimşek et al. (2017) found similar results in the sense that social studies and primary school teacher candidates perceived themselves as insufficient in terms of citizenship education. The results are also similar to Yigit's (2017) study in terms of teachers' perception of selfinadequacy concerning the value and skill dimensions (active participation, thinking, etc.) of citizenship. In addition, teachers consider themselves inadequate when it comes to extracurricular activities in the context of citizenship education, which corresponds with the results of Som and Karataş (2015). 
Curriculums help organize education in schools. Citizenship education is also provided to raise effective citizens through programs. In this study, the participants think that if the philosophy of the program matches student ideology, the student's citizenship education is affected positively, and if it does not match with student ideology, the student's citizenship education is affected negatively. Similarly, the preparation of secondary education programs by field experts, giving consideration to development of critical thinking, seeing citizenship education as a goal, supporting the affective development and socialization of students, giving citizenship gain and its concepts are seen as positive for citizenship education. Negative factors arising from program planning are: the program is frequently updated, it is not based on sustainable ideology, the priorities of program objectives are not clear, it centers on individuality, and there is a lack of time, lack of citizenship, and lack of connection with daily life. Kondu \& Sakar (2013) believe it is important to increase the number of hours given to courses including citizenship education for students to understand citizenship issues. Çelik (2009) state in his research that teachers think it is important to connect with daily life, putting citizenship education into practice; Wilkins (2003) states that teachers consider the role of schools in providing good citizenship as positive, but they think that there is a high workload and that fixed programs have negative effects on citizenship education.

\section{Suggestions}

This study aimed to investigate the factors related to school, environment, teacher, student, and program that affect citizenship education according to the opinions of secondary school teachers. The results of the study show that both informal and formal education are thought to be effective in citizenship education. The participants coded the concepts of citizenship and citizenship education as an individual, state, rights, responsibility, and so on, which is similar to the literature. Participants think that citizenship education is affected positively in terms of multiculturalism, upper socio-economic level, the family's good education, a strong physical infrastructure, media, peer groups, thinking competence, learning motivation, effective teaching, positive role model teacher, and supporting thinking through the curriculum. However, it is thought that situations such as a lower socio-economic level, media, peer groups, low education level of the environment the students' development and personality traits, mass media, lack of questioning in students, lack of effective teaching, a negative point of view from the teacher, frequent updating of the program and so on have negative effects on citizenship education. In line with these results, the following recommendations are presented:

This study was designed according to the phenomenological method. In different studies, teachers' teaching practices can be observed; in order to support students' citizenship values, competencies development and solve problems in this process, action research can be designed. This research was conducted with teachers in secondary education in terms of teaching level. Different studies may focus on the perspectives of science teachers in citizenship education. It is understood that the implicit structure of the school and environment and informal learning (family, relatives, peers, etc.) on citizenship education are effective. For this reason, protocols can be organized with provincial and district directorates of the Ministry of National Education, and cooperative studies can be carried out, especially with the families, about citizenship education. It is thought that the media have positive and negative effects on citizenship education. Therefore, students' acquisition of media literacy and critical thinking skills should be supported. Apart from teachers' role modeling, teaching competencies are also important in citizenship education. In this context, support should be provided to teachers through inservice training. The place of curriculums in citizenship education is also important. It is perceived as a problem that teachers cannot adapt to frequently changed and updated teaching programs. Therefore, it is important to prepare the curriculum within a sustainable understanding.

\section{Acknowledgements}

This paper was presented at the 6th International Congress on Curriculum and Instruction, 11-13 October 2018, in Kars, Turkey. 


\section{REFERENCES}

Acun, İ., Demir, M., \& Göz, N. L. (2010). The relationship between student teachers' citizenship skills and critical thinking skills. Journal of Social Studies Education Research, 1(1), 107-123.

Akdağ, H., \& Taşkaya, S. M. (2010). Vatandaşlık ve insan hakları eğitiminin sosyal bilgiler öğretimindeki yeri [The place of citizenship and human rights education in social studies education]. In R. Turan \& K. Ulusoy (Eds.), Sosyal bilgilerin temelleri [Basics of social studies]. (pp.85-111). Ankara: Maya Academy Publishing.

Al-Sabeelah, A. M. S., Alraggad, F. E. A., \& Abou-Ameerh, O. A. (2015). The dimensions of the citizenship concepts among the Jordanian University students. International Education Studies, 8(8), 87-102. DOI: 10.5539/ies.v8n8p87.

Arslan, S. (2014). Towards citizenship education in multicultural societies investigation of teacher and student thought (Unpublished doctoral dissertation). University of Marmara, İstanbul.

Atasoy, T., \& Koç, H. (2015). The role of geography teaching in active citizenship education: The opinion of faculty members. Journal of World of Turks, 7(2), 113-131.

Balkaya, A., \& Ceyhan, E. (2007). Investigating the levels of sense of identity acquisition of high school students in terms of some variables. Anadolu University Journal of Social Sciences, 7(1), 433-446.

Barr, R., Barth, J. L., \& Shermis, S. S. (2013). Sosyal bilgilerin doğası [The nature of the social studies] C. Dönmez (Trans. Ed.). Ankara: Pegem Publishing.

Başaran, T. (2007). Program of citizenship and human rights education at primary school level from the stand point of social science teachers (Unpublished master's thesis). University of Trakya, Trakya.

Berlach, R. (1996). Citizenship education: Australian and Singaporean perspectives. Australian Journal of Teacher Education, 21(2),1-15. DOI: 10.14221/ajte.1996v21n2.1

Bıçak, İ., \& Ereş, F. (2018). Teachers' views concerning citizenship education and the citizenship education process. The Journal of Turkish Educational Sciences, 16(2), 257-279.

Biesta, G. J. J., Lawy, R. S., \& Kelly, N. (2009). Understanding young people's citizenship learning in everyday life: The role of contexts, relationships and dispositions. Education, Citizenship and Social Justice, 4(1), 524. DOI: $10.1177 / 1746197908099374$

Brooks, R. M., \& Holford, J. A. K. (2009). Citizenship, learning and education: Themes and issues. Citizenship Studies, 13(2), 85-103. DOI: 10.1080/13621020902749027

Burton, D., \& May, S. (2015). Citizenship education in secondary schools in England. E-Journal of the British Education Studies Association, 7(1), 76-91.

Büyüköztürk, Ş., Kılıç Çakmak, E., Akgün, Ö. E., Karadeniz, Ş., \& Demirel, F. (2014). Bilimsel araştırma yöntemleri [Scientific research methods] (18th ed.). Ankara: Pegem Publishing.

Cornbleth, C. (2010). Images of America: What youth do know about the United States. American Educational Research Journal, 39(2), 519-552. DOI: 10.3102/00028312039002519

Creswell, J. W. (2012). Nitel araştırmalar için 30 temel beceri [30 essential skills for the qualitative researcher] (Trans. H. Özcan). Ankara: Anı Publishing.

Creswell, J. W. (2016). Beş nitel araştırma yaklaşımı [Five qualitative approaches to inquiry]. In M. Bütün \& S. B. Demir (Eds.), Nitel araştırma yöntemleri: Beş yaklaşıma göre nitel araştırma ve araştırma deseni [Qualitative inquiry \& research design: Choosing among five approaches]. (pp. 69-110) (Trans. M. Aydin). Ankara: Political Bookstore Publishing.

Creswell, J. W., \& Miller, D. L. (2000). Determining validity in qualitative inquiry. Theory Into Practice, 39(3),124-130. DOI: 10.1207/s15430421tip3903_2

Çelik, H. (2009). Wiews of social studies teachers related to the present circumstance and future of citizenship education (Unpublished doctoral dissertation). University of Marmara, İstanbul.

Çiftçi, A. (2006). Vatandaşlık bilgisi: Demokrasi ve insan hakları [Citizenship knowledge: Democracy and human rights]. Ankara: Gündüz Education and Publishing.

Dejaeghere, Y., \& Hooghe, M. (2009). Briefreport: Citizenship concepts among adolescents. Evidence from a survey among Belgian 16-year olds. Journal of Adolescence, 32(3), 723-732. DOI:10.1016/j.adolescence.2009.01.007

Doğanay, A. (2003). Sosyal bilgiler öğretimi [Teaching social studies]. In C. Öztürk \& D. Dilek (Eds.), Hayat bilgisi ve sosyal bilgiler ögretimi [Teaching life studies and social studies] (pp. 15-46). Ankara: Pegem Publishing. 
Doğanay, A. (2009). The evaluation of prospective teacher's perception and practices of citizenship in the context of political socialization. In A. Şişman et al. (Eds.), I. International European Union, Democracy, Citizenship and Citizenship Education Symposium (pp.28-44). Uşak: Uşak University.

Doğanay, A., \& Sarı, M. (2009). Analysis of the factors that effect citizenship perceptions of high school students. In A. Şişman et al. (Eds.), I. International European Union, Democracy, Citizenship and Citizenship Education Symposium (pp. 45-62). Uşak: Uşak University.

Ekici, Ö. (2018). Social studies teachers' opinions on the problems in citizenship education at secondary schools (Unpublished doctoral dissertation). Atatürk University, Erzurum.

Engin, G., \& Sarsar, F. (2015). Investigation of primary school teacher candidates' global citizenship levels. International Journal of Human Sciences, 12(1), 150-161. DOI: 10.14687/IJHS. V12I1.3159

Engle, S. H., \& Ochoa, A. (1988). Education for democratic citizenship: Decision making in the social studies. New York: Teacher College Press.

Er, H., Ünal, F., \&. Özmen, C. (2013). A research on the views related to the application of the citizenship and democracy education course in fourth class. The Journal of Academic Social Science Studies, 6(8), 179196. DOI: $10.9761 /$ JASSS1961

Ersoy, A. F. (2016). Social studies teachers' and students' perception of the citizenship and democracy education course. Inönü University Journal of the Faculty of Education, 17(13), 67-83. DOI: 10.17679/iuefd.17345163

Evans, M. (2006). Educating for citizenship: What teachers say and what teachers do. Canadian Journal of Education, 29 (2), 410-435. DOI: $10.2307 / 20054170$

Güven, S. (2002). 7th- 8th grades citizenship and human rights courses teachers effectiveness and their problems in teaching: Erzincan sample (Unpublished master's thesis). Atatürk University Institute of Social Sciences, Erzurum.

Güven, S. (2010). A case study on the primary grades civics education (Unpublished doctoral dissertation). University of Gazi, Ankara.

Güven, S., Tertemiz, N., \& Bulut, P. (2009). Views of class teachers on citizenship and citizenship education. The Black Sea Journal of Social Sciences, 1(1), 149-170.

Hablemitoğlu, Ş., \& Özmete, E. (2012). A suggestion for effective citizenship education. Journal of Ankara Health Sciences 1(3), 39-54. DOI: 10.1501/ASBD_0000000028

Hoge, J. D. (2002). Character education, citizenship education, and the social studies. The Social Studies, 93(3), 103-108. DOI: 10.1080/00377990209599891

İkinci, İ. (2016). Investigation of social studies teachers' perceptions of citizenship and citizenship education (Unpublished doctoral dissertation). Dumlupınar University, Kütahya.

Juanjuan, Z. (2013). Citizenship education and foreign language learning: Deconstructing the concept of good citizenship embedded in foreign language curricula in China and America (Unpublished doctoral dissertation). Utah State University, Logan, Utah.

Kakos, M., \& Palaiologou, N. (2014). Intercultural citizenship education in Greece: Us and them. Italian Journal of Sociology of Education, 6(2), 69-87. DOI:10.14658/pupj-ijse-2014-2-4

Kan, Ç. (2009). Global citizenship in social studies education. Pamukkale University Journal of Education, 26(26), 25-30.

Keleş, H., \& Tonga, D. (2014). Teacher views about factors affecting students' citizenship consciousness. Bolu Abant İzet Baysal University Journal of Faculty of Education, 14(2), 61-85.

Kennedy, K. J. (2012). Global trends in civic and citizenship education: What are the lessons formation states? Educ. Sci., 2(3), 121-135. DOI: 10.3390/educsci2030121

Kılınç, E., \& Dere, İ. (2013). High school students' perception of the concept of 'good citizen'. Journal of Social Studies Education Research, 4(2), 103-124.

Kondu, Z., \& Sakar, T. (2013). Why do we give education about citizenship and democracy? Mehmet Akif Ersoy University Journal of The Institute of Educational Sciences, 2(3), 49-60.

Koutselini, M. (2008). Citizenship education in context: Student teacher perceptions of citizenship in Cyprus. Intercultural Education, 19(2), 163-175. DOI:10.1080/14675980801889690

Mahmood, H. (2014). Civics and citizenship education in Malaysia: The voice of micropolicy enactors (Unpublished doctoral dissertation). Cardiff University, United Kingdom.

Martin, L. A. (2010). A comparative analysis of teacher education students' views about citizenship education. Action in Teacher Education, 32(2), 56-69. DOI: 10.1080/01626620.2010.10463550

Martin, L.A. (2008). Elementary and secondary teacher education students' perspectives on citizenship. Action in Teacher Education, 30(3), 54-63. DOI: 10.1080/01626620.2008.10463502

Merey, Z., Karatekin, K., \& Kuş, Z. (2012). Citizenship education on elementary level: A theoretical comparative study. Journal of Gazi Education Faculty,32(3), 795-821. 
Merriam, B. (2013a). Nitel araştırma türleri [Six common qualitative research designs]. In S. Turan (Ed.), Nitel araştırma desen ve uygulama için bir rehber [Qualitative research a guide to design and implementation] (pp.21-37) (Trans. F.K. Canbaz \& M. Öz). Ankara: Nobel Academic Publishing.

Merriam, B. (2013b). Nitel araştırmalarda geçerlik, güvenirlik ve etik [Dealing with validity, reliability, and ethics]. In S. Turan (Ed.), Nitel araştırma desen ve uygulama için bir rehber [Qualitative research a guide to design and implementation] (pp.199-228) (Trans. E. Dinç). Ankara: Nobel Academic Publishing.

Misırl1-Özsoy, A. (2010). 8th grade students' perceptions of civic issues and participation in electoral, political and civic activities (Unpublished doctoral dissertation). Middle East Technical University, Ankara.

Miles, B. M., \& Huberman, A. M. (1994). Qualitative data analysis (2nd ed.). SAGE Publication, Thousand Oaks, California.

Morsünbül, Ü., \& Çok, F. (2013). A new dimension in identity development: Ruminative exploration. Turkish Psychological Counseling and Guidance Journal, 5(40), 232-244.

Osborne, K. (1991). Teaching for democratic citizenship. Toronto, ON: Our Schools/OurSelves Foundation.

Osler, A., \& Starkey, H. (2006). Education for democratic citizenship: A review of research, policy and practice 1995-2005. Research Papers in Education, 24(4),433-466. DOI:10.1080/02671520600942438

OXFAM, (2015). Education for global citizenship a guide for schools. Oxford, UK: Oxfam GB. Retrieved from https://www.oxfam.org.uk/education/resources/education-for-global-citizenship-a-guide-for-schools.

Öksüz, Y., \& Kansu, C. Ç. (2015). According to the opinions of teachers and students active citizenship education in elementary school. Mevlâna International Journal of Education, 5(1), 10-25. DOI: 10.13054/mije.14.61.5.1

Özmen, C. (2011). Teachers opinions related to citizeship transmission approach in social studies education. Mustafa Kemal University Journal of Social Science Institute, 8(15), 435-455.

Patton, M. Q. (2014). Nitel araştırmada çeşitlilik, kuramsal yönelimler [Variety in qualitative inquiry: Theoretical orientations]. In M. Bütün \& B. Demir (Eds.) Nitel araştırma ve dĕgerlendirme yöntemleri [Qualitative research \& evaluation methods] (pp.75-118) (Trans. E. Bukova Güzel \& H. Demircioğlu). Ankara: Pegem Publishing.

Penner, J., \& Sanderse, J. (2017). The role of economic citizenship education in advancing global citizenship. Policy \& Practice: A Development Education Review, 24, 138-158.

Pontes, A. I., Henn, M., \& Griffiths, M. D. (2019). Youth political (dis)engagement and the need for citizenship education: Encouraging young people's civic and political participation through the curriculum. Education, Citizenship and Social Justice, 14(1) 3-21. DOI: 10.1177/1746197917734542

Print, M., \& Smith, A. (2000). Teaching civic education for a civil, democratic society in the Asian region. Asia Pacific Education Review, 1(1), 101-109.

Remy, R. C. (1978). Social studies and citizen ship education: Elements of a changing relationship. Theory and Research in Social Education, 6(4), 40-59. DOI: 10.1080/00933104.1978.10506044

Ribble, M. S., Bailey, G. D., \& Ross, T. W. (2004). Digital citizenship: Addressing appropriate technology behavior. Learning \& Leading with Technology, 32(1), 6-9.

Sağlam, H. İ., \& Hayal, M. A. (2015). The views of class teachers on the incorporation of human rights, citizenship and democracy courses in the curriculum of fourth graders. Bolu Abant Izzet Baysal University Journal of Faculty of Education, 15(1), 207-217.

Schattle, H. (2008). Education for global citizenship: Illustrations of ideological pluralism and adaptation, Journal of Political Ideologies, 13(1), 73-94. DOI: 10.1080/13569310701822263

Schugurensky, D., \& Myers, J. P. (2003). Citizenship education: Theory, research, and practice. Encounters on Education, 4, 1-10. DOI: 10.24908/eoe-ese-rse.v4i0.655

Schuler, D. (2002). Digital cities and digital citizens. In M. Tanabe, P. Van den Besselaar \& T. Ishida (Eds), Digital Cities 2001: Digital Cities II: Computational and Sociological Approaches (pp.71-85). Lecture Notes in Computer Science, Springer, Berlin, Heidelberg. DOI:10.1007/3-540-45636-8_6

Seiger, T. M. (1996). Global citizenship a model for student inquiry and decision making (Unpublished doctoral dissertation). The University of Arizona, USA.

Som, İ., \& Karataş, H. (2015). A review on citizenship education in Turkey. Uşak University Journal of Educational Research, 1(1), 33-50. DOI: 10.29065/usakead.232402

Stuen, C. (1996). Elementary teachers' perception of the characteristics and development of good citizenship in Washington (Unpublished doctoral dissertation). Seattle Pacific University, Seattle.

Sunal, C. S., \& Haas, M. E. (2002). Social studies for the elementary and middle grades: A constructivist approach. Boston: Allynand Bacon.

Şahin, Ş., \& Çövener Özçelik, Ç. (2016). Adolescence and socializing. Cumhuriyet Nursing Journal, 5(1), 42-49.

Şimşek, U., Tıkman, F., Yıldırım, E., \& Şentürk, M. (2017). The views of pre-service social studies teachers and pre-service classroom teachers about citizenship education: A qualitative study. Journal of Ziya Gökalp Education Faculty, 32, 913-925. DOI: 10.14582/DUZGEF.1871 
Torney-Purta, J., Lehmann, R., Oswald, H., \& Schulz, W. (2001). Citizenship and education in twenty-eight countries civic knowledge and engagement at age fourteen. Amsterdam: International Association for the Evaluation of Education Achievement.

Torney-Purta, J., Richardson, W. K., \& Barber, C. H. (2005). Teachers' educational experience and confidence in relation to students' civic knowledge across countries. International Journal of Citizenship and Teacher Education, 1(1), 32-52.

Torney-Purta, J. (2002). The school's role in developing civic engagement: A study of adolescents in twenty-eight countries. Applied Developmental Science,6(4),203-212. DOI: 10.1207/S1532480XADS0604_7

Uğurlu, C. T. (2011). Citizenship education in European Union countries and Turkey. Electronic Journal of Social Sciences, 10(37), 153-169.

Ulutaş, E. (2014). Constitutional process and citizenship in Turkey. Journal of Academic Inquiries, 9(1),73-102. DOI: $10.17550 /$ aid.68423

UNESCO, (2014). Global citizenship education, preparing learners for the challenges for the twenty-first century. Retrieved from https://unesdoc.unesco.org/ark:/48223/pf0000227729.

Uydaş, İ., \& Genç, S. Z. (2015). Evaluating high school students' views on multiculturalism within the framework of global citizenship. International Journal of Turkish Literature Culture Education, 4(1), 416-429. DOI: 10.7884/teke.396

Ülger, M., \& Yel, S. (2013). Primary school teachers' competency perception related to human rights and citizenship education as an inter-discipline domain. International Journal of Eurasia Social Sciences, 4(10), 19-32.

Ünal, F. (2012). An analysis on human rights in citizenship and democracy curriculum and textbooks of 8th elementary education. Bartın University Faculty of Education Journal, 1(1), 110-127.

Veldhuis, R. (1997). Education for democratic citizenship: Dimensions of citizenship, core competencies, variables, and international activities. Strasbourg: Council of Europe.

Veugelers, W. (2007). Creating critical-democratic citizenship education: Empowering humanity and democracy in Dutch education. Compare: A Journal of Comparative and International Education, 37(1), 105-119. DOI: $10.1080 / 03057920601061893$

Veugelers, W. (2011). The moral and the political in global citizenship: Appreciating differences in education. Globalization, Societies and Education Societies and Education, 9(3-4),473-485. DOI: $10.1080 / 14767724.2011 .605329$

Wilkins, C. (2003). Teachers and young citizens: Teachers talk about their role as social educators. Westminster Studies in Education, 26(1), 63-75. DOI:10.1080/0140672030260106

Yıldırım, A. \& Şimşek. H. (2016). Sosyal bilimlerde nitel araştırma [Qualitative research in social sciences] (10th ed.). Ankara: Seçkin Publishing

Y1lmaz, K. (2013). An investigation into elementary school students' perceptions of basic concepts about citizenship education. Hacettepe University Journal of Education, 28(1),453-463.

Yiğit, E. Ö. (2017). Citizenship and Turkish citizenship in views of pre-service social studies teachers. Elementary Education Online, 16(2), 406-427. DOI: 10.17051/ilkonline.2017.304708. 


\section{TÜRKÇE GENIŞLETILMIŞ ÖZET}

Vatandaşlık özelliklerinin dün ne olduğu, bugün neleri kapsadığı, yarın nelerden oluşacağı bireylerin nasıl algılandığına, nasıl yönetildiğine ve onlardan neler beklendiğiyle ilgilidir. Günümüzde hızla gelişen teknolojinin uzaktaki bireyleri yakınlaştırması, kültürler arası aktarımı kolaylaştırması, farklı topraklarda yaşayan milyonlarca insanın ortak evrensel değerler oluşturması, bu değerleri anlaması ve eylemde bulunması küresel vatandaşlık kavramını yaratmakta (OXFAM, 2015, s. 5; Penner \& Sanderse, 2017; Schattle, 2008; UNESCO, 2014); şehirlerin dijitalleşmesi, teknolojinin günlük yaşamın bir parçası olması onu etkin, norma uygun ve etik kullanma bilgi ve becerisini içerdiğinden dijital vatandaşlık kavramını (Ribble, Bailey, \& Ross, 2004; Schuler, 2002) oluşturmaktadır. Dolayısıyla değişimlerin vatandaşlık kavramına küresel, dijital vb. birçok yeni değer ve anlam yüklediği görülmektedir. $\mathrm{Bu}$ araştırmada ise, vatandaşlık kavramını ulusal vatandaşlık algısı ve eğitimi bağlamında ele alınmaktadır.

Vatandaşlık eğitimi bireyin etkili bir vatandaş olması için gereken bilgi, beceri ve değerlerin öğretimini içermektedir. Sosyal bir varlık olan bireyin aidiyetliği, toplumsallaşması için gereklidir. Osborne (1991, s. 13) okulların hem bireyin toplumsallaşmasını sağladığını hem de çeşitli derslerle vatandaşlık eğitimini verdiğini belirtmekte ve bu eğitimin de yaşam boyu devam eden dinamik bir süreç olduğunu ifade etmektedir. Remy (1978) lise ve ilköğretim okullarında vatandaşlık gelişiminin formal ve informal eğitim süreçlerinin odak noktası olduğunu ifade etmektedir. Torney-Purta, Lehmann, Oswald, ve Schulz (2001, s. 21) toplumun değer ve kazanımlarıyla yetişen bireylerin, vatandaşlık eğitiminin odağında yer aldığını belirtmektedirler. Bu gelişim sürecinde politika, eğitim, ekonomi, sosyoloji, din, sözlü edebiyat, uluslararası ilişkiler, medya (iletişim) vb. disiplinlere ait olgu ve durumların etkili olduğunu açıklamakta; vatandaşlık kazanımlarının okul, öğretmen, eğitim programı, akran grupları (okul içinde ve okul dışında), aile (ebevyn/kardeş), komşular, göç, dil, cinsiyet, televizyon gibi unsurlardan bağımsız olamayacağına değinmektedirler. Vatandaşlık eğitimi liselerde tarih, ekonomi, coğrafya ve diğer sosyal bilimler derslerinde temel bir amaç olarak kabul edilmektedir (Hoge, 2002). Som ve Karataş'a (2015) göre de vatandaşlık eğitiminin tek başına öğretim programında bir ders olmasının yanında diğer derslere entegre edilerek verilmesi önemlidir. 2018-2019 eğitim öğretim y1llarında uygulanan ortaöğretim programlarında da derslerin farklı disiplinlerle ve günlük hayatla ilişkilendirildiği bütünleşik bir anlayışın olduğu vurgulanmıştır. Ayrıca programlarda Türkiye Yeterlikler Çerçevesi (TYÇ) dikkate alınarak hazırlanan ve öğrenenlerin bilgi, beceri, tutum ve değer gelişimini destekleyen sekiz anahtar yetkinliğe yer verilmiştir. Bu yetkinliklerden biri de tüm derslerde vatandaşlık yetkinliğinin öğrencilere kazandırılmasıdır. Vatandaşlık yetkinliğinde amaç, bireyleri toplumsal ve siyasal kavramlara ilişkin bilgilerle donatmak; demokratik ve aktif katılıma dayalı medeni hayata dâhil olmalarını sağlamaktır.

Bilindiği üzere, öğretmenler hazırlanan programların sahadaki uygulayıcısıdır ve onlardan programları yaşatmaları beklenmektedir. Öğretmenler vatandaşlık eğitimini etkileyen faktörlere doğrudan maruz kaldıkları için sürecin onların gözünden incelenmesi önem arz etmektedir. Ayrıca vatandaşlık eğitiminde toplum, okul, aile, öğrenci değişkenleri birlikte ele alınmalı ve değerlendirilmelidir (Uğurlu, 2011). Bu araştırmayla da vatandaşlık eğitimini etkileyen durumların bütün olarak görülmesine ve eğitim düzenlemelerinin zenginleştirilmesine yarar sağlanacağı düşünülmektedir. Araştırmada ortaöğretim kademesindeki vatandaşlık eğitimini etkileyen faktörlerin coğrafya, felsefe, tarih öğretmenlerinin algılarına ve deneyimlerine göre değerlendirilmesi amaçlanmaktadır. Bu genel amaç doğrultusunda aşağıda yer alan alt amaçlara cevap aranmıştır:

Ortaöğretim öğretmenleri vatandaşlığı ve vatandaşlık eğitimini nasıl kavramsallaştırmaktadır?

Ortaöğretim öğretmenlerinin vatandaşlık yetkinliğini kazandırma sürecine ilişkin öğretim deneyimleri nelerdir? 
Ortaöğretim öğretmenleri öğrencilerinde vatandaşlık gelişimini etkileyen okul, çevre, öğrenci, öğretmen, program kaynaklı olumlu ve olumsuz faktörleri ve nedenlerini nasıl tanımlamakta ve açıklamaktadırlar?

Araştırma nitel bir araştırma olup, olgu bilime göre desenlenmiştir. Olgu bilim araştırmaları birkaç kişinin bir fenomen veya kavramla ilgili yaşanmış ortak anlamını tanımlar (Creswell, 2016, s. 77). Bu araştırma sürecinde deneyimin bilince dönüşme sürecine odaklanılarak deneyimin anlamının ve doğasının derinlemesine ortaya konulması amaçlanır (Merriam, 2013a, s. 24; Patton, 2014, s. 104). Bu araştırmada da ortaöğretim öğretmenlerinin vatandaşlık eğitimine ilişkin algılarının ve deneyimlerinin derinlemesine incelenmesi üzerinde durulmuştur. Katılımcıların seçiminde maksimum çeşitlilik dikkate alınmış ve katılımcılar 2017-2018 eğitim öğretim yılı bahar döneminde Gaziantep ilinin Şahinbey ilçesinde 3 farklı ortaöğretim kurumunda görev yapan 8 öğretmenden (coğrafya, tarih, felsefe) oluşmuştur. Araştırmadan önce Şahinbey İlçe Milli Eğitim Müdürlüğü’nden gerekli izinler alınmıştır. Ayrıca araştırmaya katılan öğretmenlerin gönüllü olmaları esas kılınmıştır. Araştırmada veriler araştırmacıların geliştirdiği yarı yapılandırılmış görüşme formu yoluyla toplanmıştır. Veriler içerik analizi yoluyla analiz edilmiştir ve nedensel ağlarla gösterilmiştir.

Araştırmadan ortaya çıkan sonuçlar katılımcı öğretmenlerin vatandaşlık ve vatandaşlık eğitimi kavramlarını birey, devlet, hak, sorumluluk vb. şekilde literatürle benzer kodladıkları görülmektedir. Araştırmada katılımcıların tamamının öğretim süreçlerinde vatandaşlık bilgi ve becerisine yönelik çalışmalar yaptıkları, bu süreçte de öğretim programı içeriğinin dikkate alındığı, disiplinler arası öğretim yapıldığı ve informal (plansız) eğitim yoluyla vatandaşlık eğitimini gerçekleştirildiği görülmektedir. Vatandaşlık eğitimleri okul, öğretmen, öğrenci, çevre ve program bağlamları kapsamında incelenmiş ve vatandaşlık eğitimi üzerinde formal eğitim kadar informal eğitimin de etkili olduğunun düşünüldüğünü ortaya çıkmıştır. Katılımcılara göre, vatandaşlık eğitimi çok kültürlülük, üst sosyoekonomik düzey, ailenin iyi eğitimi, güçlü fiziki alt yapı, medya, akran grupları, düşünme yeterliliğii, öğrenme güdüsü, etkili öğretim, olumlu rol model öğretmen, programın düşünmeyi desteklemesi vb. açılardan olumlu yönde etkilenmektedir. Ancak alt sosyoekonomik düzey, medya, akran grupları, çevrenin düşük eğitim seviyesi, öğrencilerin gelişim ve kişilik özellikleri, kitle iletişim araçları, öğrencilerin sorgulama yetersizliği, etkili öğretim yetersizliği, öğretmenin olumsuz bakış açısı, programın sık güncellenmesi vb. durumların vatandaşlık eğitimi üzerinde olumsuz etkilerinin olduğu düşünülmektedir. 